Reprod. Nutr. Dévelop., 1988, 28 (4 B), 1047-1080

\title{
In vitro maturation of sheep ovarian oocytes
}

\author{
D. SZÖLLÖSI (1), Véronique DESMEDT, Nicole CROZET, Corinne BRENDER \\ Technical assistance: Denise HUNEAU
}

Biologie de la Fécondation, Laboratoire de Physiologie Animale, I.N.R.A., F-78350 Jouy-en-Josas, France.

\begin{abstract}
Summary. An in vitro system has been developed which induces full meiotic maturation in $98 \%$ ovarian sheep oocytes isolated from follicles $2-6 \mathrm{~mm}$ in diameter. $45.7 \%$ of these were fertilized, determined by the presence of two pronuclei, extrusion of the second polar body and the presence of the sperm flagellum.

This culture system was used to describe the morphological changes during meiotic maturation, examining the nucleus, the cytoplasm and cumulus (corona)-oocyte relationship. $24 \mathrm{~h}$ are required for maturation of sheep oocytes. The culture medium must contain FSH, LH $\left(10 \mu \mathrm{g} / \mathrm{ml}\right.$ of each), estradiol $-17 \beta(1 \mu \mathrm{g} / \mathrm{ml})$ and coculture of $10^{6}$ mural granulosa cells in suspension (Crozet et al., 1987).

Nuclear changes were the first evident transformations, showing that chromatin condensation leads to nuclear deformation, to germinal vesicle breakdown and to formation of the first and second meiotic metaphases. The axis of both spindles are oriented perpendicularly to the egg membrane. At each pole a bent disc composed of filamentous material represents the microtubule organizing centers (MTOC). The key event may be the initiation and control of chromosome condensation.

Cytoplasmic changes include the development of a cortical layer of 1-4 $\mu \mathrm{m}$ thickness poor in cell organelles. Golgi complexes are localized in three distinct areas with possibly different functions: (1) around the germinal vesicle; (2) in the oocyte cortex, of regular distance; (3) in the central part of the oocyte. Cortical granules (CG) of different maturation stages (condensation) form clusters near the peripheral Golgi complexes while at Meta I they form a nearly continuous single layer. At Meta II the CGs are apparently anchored to the cell membrane by means of small spokes.

The cumulus (corona) cells are attached by junctional complexes to each other and to the ocyte. Foot processes cross the zona and indent the oocyte. The termini are gradually exteriorized and contacts must be broken to isolate the oocyte.

The sum of all the above changes represent meiotic maturation.
\end{abstract}

\section{Introduction.}

For development of fertilizable mammalian oocytes the meiotic processes, initiated and then arrested during fetal life, have to be completed. Also, the intercellular junctional relationships permitting nutrient supply of the oocyte

(') Correspondence to: Daniel Szöllösi, address as above. 
established at the moment of follicle formation between the oocytes and a specific set of somatic cells, the follicle cells, must be modified and then terminated. In order that normal embryonic development can follow fertilization the interrupted meiotic processes must be completed and the oocytes must free themselves from dependence on their associated cell population. Specialized junctional complexes transformed the cumulus-oocyte complexes (COC) into a physiological syncytium. These changes, in their totality, can be defined as meiotic maturation.

Both of these processes occur in vivo either under a protracted influence of the discharged endogenous gonadotrophic hormones or following the administration of isolated and purified hormones (Sato and Koide, 1987 ; Schultz, 1987 ; Thibault et al., 1987). Despite the fact that the oocytes already reached their full size close to the time of antrum formation and have completed their essential synthetic activities they must undergo the complex, final maturation events in both cellular compartments, the nucleus and cytoplasm.

When oocytes are set free from large, antral follicles and placed into an adequate culture medium, they undergo «spontaneous maturation » when cultured for a certain number of hours. Even though sperm penetration takes place when these oocytes are exposed to sperm suspension no development follows (Thibault and Gérard, 1970 ; Thibault, 1972) with exception of the mouse (Cross and Brinster, 1970; Eppig, 1982) and rat (Flemming et al., 1985). When oocytes of similar origin are cultured, however, in the presence of gonadotrophic hormones and other appropriate conditions, normal cleavage and development ensues when inseminated in vivo or in vitro. Gonadotrophic hormone supplemented culture medium can successfully induce the normal maturation events in the oocyte and cumulus and terminate the specialized functional and morphological relationship between the oocyte and follicle cells. In sheep an in vitro maturation procedure was developed by Staigmiller and Moor (1984) giving a high rate of embryonic development. Recently an in vitro insemination and culture system was developed resulting in normal cleavage stages, which, following transfer into the reproductive tracts of synchronized, adult females lead to birth of healthy young (Crozet et al., 1987).

We have adopted Staigmiller and Moor's system (") and employed it to define in detail the temporal sequence of events involved in meiotic maturation on the cellular and ultrastructural level. Most of our work thus far serves the establishment of a baseline of normal maturation events for the subsequent comparison of different experimental culture conditions. After determination of the necessary level and pattern of hormone treatment to obtain maximal maturation conditions, the schedule and concentration of hormone treatment will be varied for more detailed analysis of the maturation process. We shall focus our attention particularly on both cell compartments, the nucleus and cytoplasm, and on the cell junctions between the gamete and follicle cells and between the follicle cells themselves. As a biological control, a few oocytes were cultured in each

() See acknowledgements. 
experiment for $24 \mathrm{~h}$, to give fully mature, Metaphase II oocytes. These were inseminated in vitro (Crozet et al., 1987) and the formation of two pronuclei and abstriction of polar body II (PB II), was accepted as the definition of « fertilized eggs » for the present experimental series.

\section{Materials and methods.}

\section{A. Oocyte maturation.}

The culture system developed by Staigmiller and Moor (1984) was adopted in its entirety. The oocyte donors were, however, not pretreated by FSH because the experimental series was started with anestrous ewes. The few cyclic females were used on days 10-12 of the cycle, also without hormone pretreatment. The animals were $7-8$ year old, lle-de-France breed.

Follicles between 2 and $6 \mathrm{~mm}$ in diameter were dissected in Dulbecco's phosphate buffered saline (PBS) with $10 \%$ of fetal calf serum (fcs), care being taken that the follicles were clear and not atretic. "COCs" were recovered and collected from the follicles. From follicles of $2-3 \mathrm{~mm}$ size range, mural granulosa cells were aspirated by a small bore glass pipette and were dispersed. The granulosa cells were centrifuged at $1200 \mathrm{~g}$ for $5 \mathrm{~min}$, washed twice, and were resuspended in TC 199-Hepes Medium and diluted to approximately $10^{6}$ cells $/ \mathrm{ml}$ for co-culturing with the COCs. For culture this medium was supplemented with $10 \mu \mathrm{g}$ of both, FSH and LH, $1 \mu \mathrm{g}$ estradiol and $15 \%$ fetal calf serum. Prolactin was omitted. The culture dishes were maintained on a rotary shaker at low speed during the entire incubation period. The temperature was kept at $39{ }^{\circ} \mathrm{C}$. The maturation schedule followed closely the schedule as reported by Staigmiller and Moor (1984). Meiotic metaphase II oocytes are found after 24 hrs of culture. Specimens were fixed for electron microscopy after 0, 5, 6, 7.5, 12, 16, 18 and $24 \mathrm{hrs}$ in culture. At each stage 2-5 oocytes were examined.

Some specimens were cultured for 0 and $6 \mathrm{hrs}$ in the medium above, containing gonadotrophins and for 24 and $18 \mathrm{hrs}$ respectively in TC 199-Hepes Medium with $1 \mu \mathrm{g} / \mathrm{ml}$ estradiol $-17 \beta$ and than they were fixed and embedded for electron microscopy.

The fixative used was a $2.5 \%$ glutaraldehyde, $0.75 \%$ paraformaldehyde solution in a 0.075 phosphate buffer (Millonig and Marinozzi, 1968) containing $0.5 \%$ potassium ferricyanide for about $1 \mathrm{hr}$. After washing the $\operatorname{COCs}(3 \mathrm{x})$ in phosphate buffer they were stored over night at $4{ }^{\circ} \mathrm{C}$. Post osmication followed next morning in a $2 \%$ aqueous osmium tetroxide solution for $45-60 \mathrm{~min}$. The COCs were then stained in toto in $0.5 \%$ aqueous uranyl acetate dehydrated directly in an ethanol series with increasing concentrations, passed through 3 baths of propylene oxide-Epon mixture of $3: 1,1: 1$ and $1: 3$ proportions. After 3-4 hrs in pure Epon embedding mixture, they were flat embedded and polymerized. Semi-thin (1/2-1 $\mu \mathrm{m})$ and thin sections were prepared for light and electron microscopy. The sections were contrasted with uranyl acetate and lead citrate. 


\section{B. Sperm capacitation and in vitro fertilization}

Fresh ejaculates obtained from rams of proven fertility were washed in $8 \mathrm{ml}$ of modified DM medium (DM-H) containing $10 \mathrm{mM}$ Hepes (Crozet et al., 1987). After centrifugation, $100 \mu \mathrm{l}$ of the pellet was overlaid with $2 \mathrm{ml}$ of DM-H medium containing $20 \%$ of heat inactivated sheep serum (s.s.) and spermatozoa were allowed to swim-up for $2 \mathrm{~h}$ at $38.5^{\circ} \mathrm{C}$. Concentration and motility of spermatozoa in the supernatant were evaluated. After dilution to $1 \times 10^{7} / \mathrm{ml}$ with the same medium spermatozoa were incubated for $5-6 \mathrm{~h}$ at $38.5^{\circ} \mathrm{C}$ under air. For fertilization preincubated spermatozoa were diluted to a concentration of $1 \times 10^{6}$ cells $/ \mathrm{ml}$ in DM-H $+20 \%$ s.s. adjusted to $\mathrm{pH} 7.7-7.8$.

In vitro matured COCs were transferred to $1 \mathrm{ml}$ of sperm suspension and incubated for $16-17 \mathrm{~h}$ at $38.5^{\circ} \mathrm{C}$ under air (DM-H). Success of fertilization was determined $17 \mathrm{~h}$ post insemination with a lacmoid stain in acetic acid (Darlington and La Cour, 1960).

\section{Results.}

Time related changes of cell organelles during meiotic maturation of sheep oocytes in culture.

\section{A. Nuclear changes}

The nucleus, the germinal vesicle (GV), of sheep oocytes from a medium or a large antral follicle $(2-6 \mathrm{~mm})$ at $0 \mathrm{~h}$ of culture is a peripherally placed, spherical structure (20-25 $\mu \mathrm{m}$ in diameter), with more or less smooth, uniform outline (fig. 1a). Pores are frequent along the nuclear envelope (NE), its inner leaflet being of slightly higer electron density than the outer one (fig. 1b). The chromatin is uniformly, highly dispersed, showing only rarely condensations. Chromatin

FIG. 1a. - The nucleus (GV) of this oocyte, collected from antral follicles (of 2-6 mm) is a large, nearly perfectly spherical structure located in the oocyte periphery. Its diameter is between 20-30 $\mu \mathrm{m}$ and only very occasionally are chromatin condensations or nucleoli visible. The corona cells are orthogonal cells which are closely applied to the zona pellucida which is crossed by their narrow foot processes. The processes end in a slightly enlarged, " button-like » terminus on the oocyte surface. 1,200 $\times$.

FIG. $1 \mathrm{~b}$. - An electron micrograph of the nuclear envelope of a sister oocyte showing many nuclear pores and a uniform perinuclear space. $32,000 \times$

FIG. 2. - A compact, small nucleolus is adjacent to a small mass of condensed chromatin. It has two parts, a very dense and a less dense portion; the latter probably represents a modified fibrillar center. $8,400 \times$.

FIG. 3. - The GW flattens against the plasma membrane and becomes crescent-shaped to an oval structure after $4-5 \mathrm{~h}$ of culture. The NE close to the plasma membrane forms few folds. Local chromatin condensations and nuclear granule accumulations are seen but particularly at NE folds. $5,500 \times$.

FIG. 4a, b. - Higher magnifications of a chromatin condensation and accumulation of nuclear granules along the $N E$. The arrow shows a corresponding level and direction the densitometric readings were taken. a. $15,000 \times$. 
aggregates are primarily seen as perinucleolar structures. There may be either a single, large nucleolus or a number of (up to 5 or 6) small nucleoli, each composed exclusively of compactly packed thin filaments. In the former case there are several peripherally located fibrillar centers (Crozet and Szöllösi, 1981) while there is a single fibrillar center associated with each small nucleolus (fig. 2 ). These nucleoli are morphologically very unusual. It was impossible to predict which type of nucleolus will be present in any given oocyte nucleus from what ever other cytological features. The small, multiple nucleoli were more frequently found.

One of the first signs of nuclear structural changes indicating initiation of maturation (between $0-5 \mathrm{~h}$ of culture) is the flatenning of the GV against the plasma membrane. The forces acting on the GV are sufficiently large to transform it into an oval to a crescent-shaped structure. The NE approches the cell membrane to within a micron over a large surface area (fig. 3). Many kinds of cell organelles are within this narrow cytoplasmic territory. The Golgi apparatus is well developped around the oocyte nucleus and it nearly begirding it. Several finger-like folds develop randomly over the nuclear surface, but the first form where the NE is close to the plasma membrane (fig. 4). Chromatin and large nuclear granules of heterogeneous size range adhere to the NE folds. The NE retains the same pore distribution and frequency as it had at the time of oocyte recovery, at time 0 . Nucleoli are rarely seen.

Seven and a half hrs of culture of oocyte with gonadotrophins represents an important turning point affecting nuclear structure. Some oocytes still contain : a) a crescent-shaped GV, flattened against the plasma membrane comparable to the GV after 5-6 h culture while in the others, chromosome condensation is noted. The chromosomes are either: b) individual structures arranged into a «star-shaped » configuration (circular bivalent stage) with folded but intact NE, or c) form a compact chromatin mass being surrounded by fragmenting, often doubled (quadruple membranes) NE segments (Szöllösi et al., 1972a).

State a) represents oocytes which react slowly to the gonadotrophic hormones in the culture system and are retarded. The two leaflets of the NE are separated by a nearly constant $25-30 \mathrm{~nm}$ wide perinuclear space. The electron density of the inner leaflet is higher and is probably of slightly greater width than the outer one (fig. 4 ; Text-fig. I). The chromosomes condense in state b) into elongated structures along which the NE becomes extensively folded and to which it adheres, forming a star-shaped configuration (fig. 5 ) ; it represents the « circular bivalent " stage. During the folding process of the NE the nucleoplasm becomes displaced from inbetween the folding envelope segments permitting the apposition of the inner leaflet of the envelope, to form « quadruple membranes" (Szöllösi et al., 1972a). The outer and inner leaflets can always be recognized already visually by the higher electron density and greater width of the inner leaflet. Densitometric scans on transparencies across the single and double envelope segments (fig. 6 ; Text-fig. I) confirm the visual impression of the higher electron density of the inner leaflet of the NE and this fact can be used reliably for the identification of the respective NE segments even when the envelope is extensively folded (fig. 5). 
Text - Fig. I
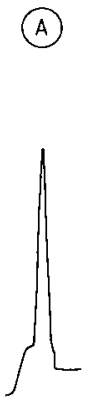
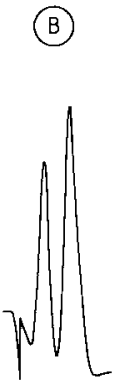
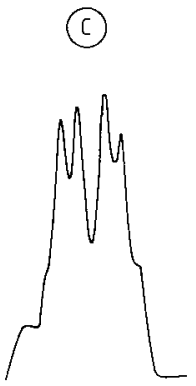
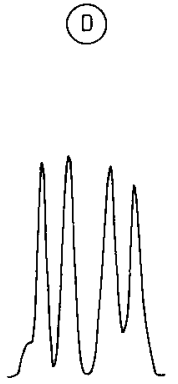

FIG. 1. - Densitometric readings were made on transparencies at $60,000 \times$ enlargements across membrane prophiles selected to be as close as possible to cross sections of : A. cell membrane (as base-line); $\mathrm{B}$. the nuclear envelope of the germinal vesicle; C. " quadruple membranes " at circular bivalent stage: D. after germinal vesicle breakdown of two adjacent membrane paires. The places marked by arrows in figures $4 a, 6$ and 8 correspond to the places and to the direction in which the readings were effected. The actual transparencies used (which would be in negative immage) are not reproduced. For further explenatin see Text.

Parallel to the folding process all nuclear pores disappear (fig. 6) (Szöllösi et al., 1972b) but the continuity of the envelope is conserved. Occasionally the first tiny breakes are visible leading finally to " germinal vesicle breakdown " (GVBD). At this time the microtubules are not seen in significant numbers neither in the perinuclear cytoplasm nor within the nucleus. Kinetochores are not yet morphologically recognizable. The nucleolus (i) is never seen. Details of the NE folding and breakdown remain to be elucidated.

When the NE breaks down, the chromosomes aggregate into a chromatin mass in the center of the nuclear sphere and the membrane remnants of the NE (state c) form a more or less spherical shell around it (fig. 7). The envelope segments are assembled into «quadruple membranes». As the breaks become more frequent, the quadruple membranes become shorter and the components of the envelope remnants start to separate. During this process the densitometric readings of the membrane pieces seen around the chromatin are the same (fig. 8a; Text-fig. I). Microtubules (Mts) polymerize in huge numbers within the area outlined by the membrane remnants of the NE corresponding to the previously existing nuclear territory. Large $\mathrm{Mt}$ bundles form within which the orientation of the individual $\mathrm{Mt}-\mathrm{s}$ are parallel but the orientation of the entire population is random (fig. $8 \mathrm{~b}, \mathrm{c}$ ). No microtubule axis nor general orientation exists for the future spindle. Fine filaments of unknown nature interlink large numbers of Mts. The microtubules are not associated with any structure which resembles « microtubule organizing centers " (MTOC) or centrosome-like material. Few kinetochores can be identified but $M$ ts pass in their immediate vicinity and do not incert on them (fig. $8 \mathrm{~b}, \mathrm{c}$ ). Mts often penetrate the condensing chromatin. Membrane structures resembling smooth endoplasmic reticulum and Golgi elements are always in proximity of the chromatin. 


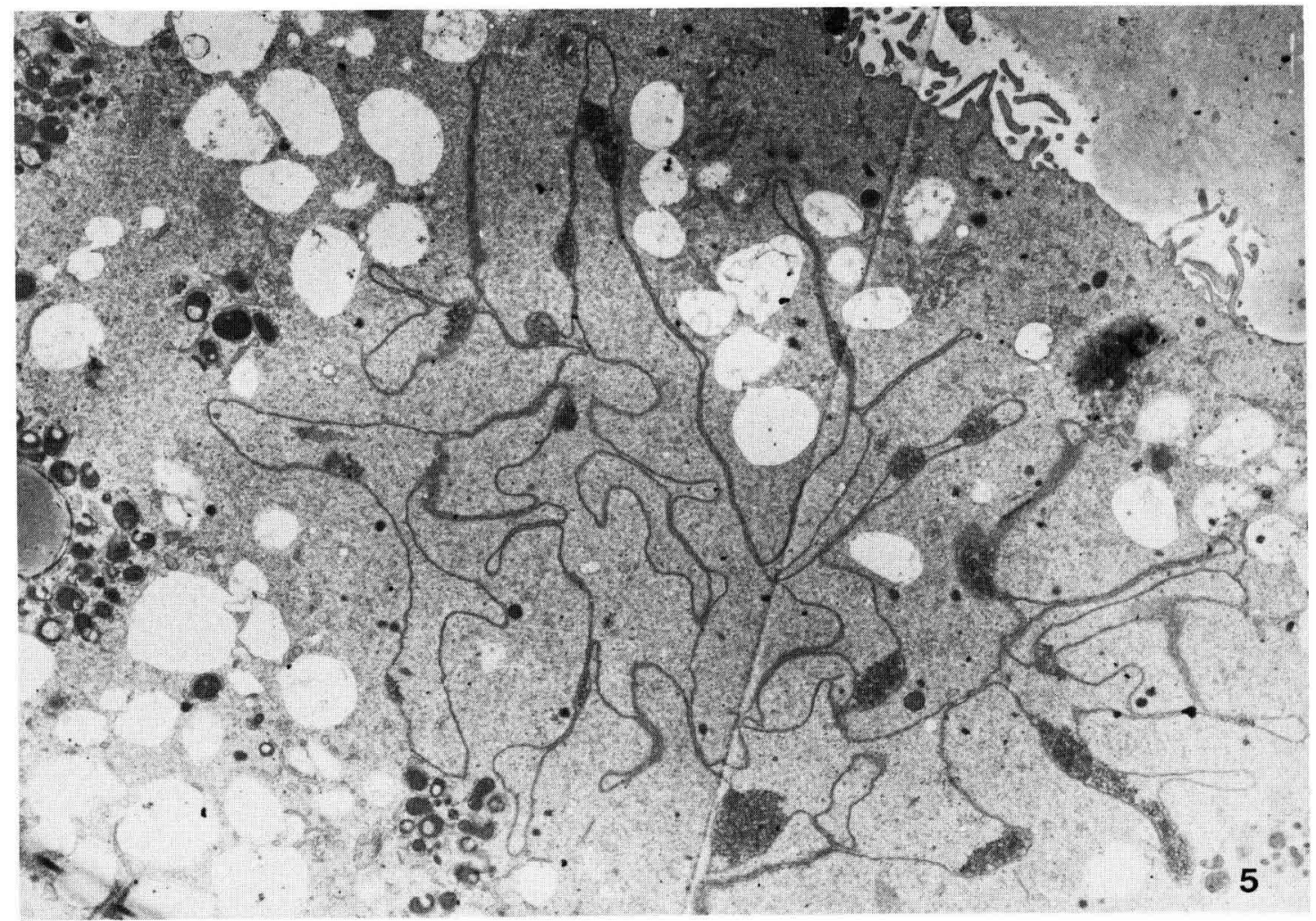

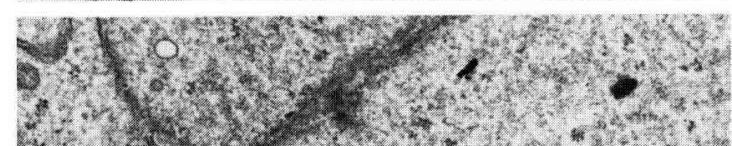

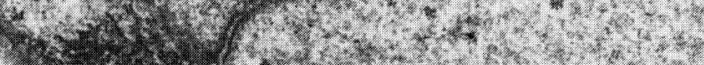

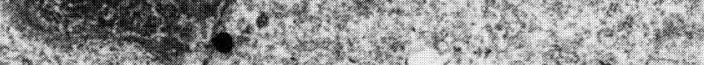

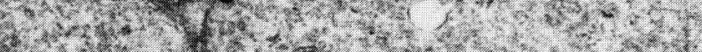

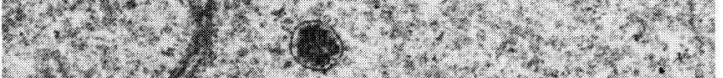

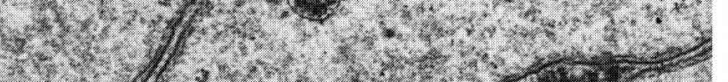

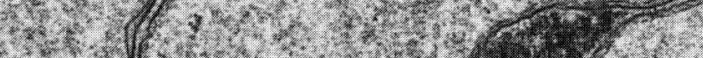

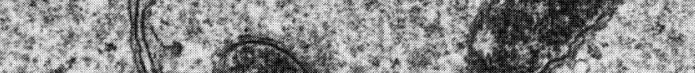

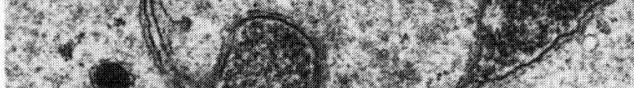

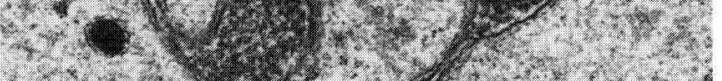

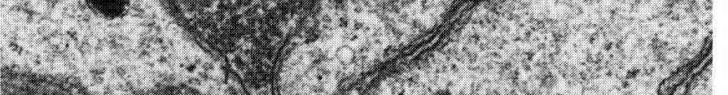
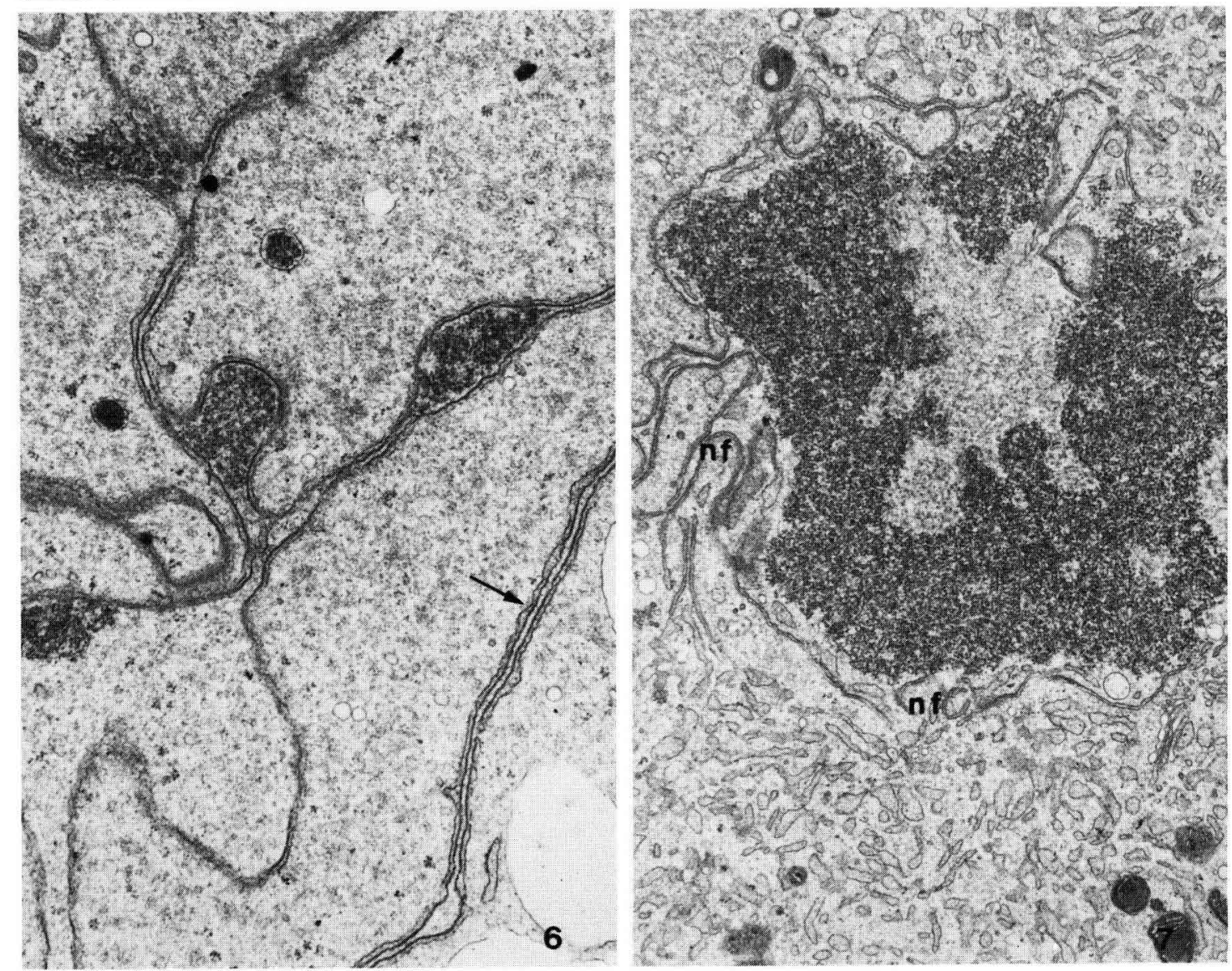
Between 7-18 h, in prometaphase the degree of chromosome condensation varies from oocyte to oocyte the individual variability being great. As metaphase-like chromosomes develop, kinetochores "mature" and form on all chromatids, their orientation being random, however. Mts finally associate with the kinetochores as formation of the metaphase plate of the first meiotic division approaches.

The first meiotic metaphase is formed between twelfth and eighteenth hours of culture. A wide barrel-shaped but short spindle is formed whose orientation is radial to the oocyte surface (fig. 9). One spindle pole is adjacent to the plasma membrane of the oocyte while the other points towards the oocyte center. The entire spindle is embedded within an homogenous, felt-like, finely filamentous material of higher electron density than the surrounding cytoplasm. The same type of material penetrates into the spindle itself along the Mt bundles and among the $\mathrm{Mts}$ themselves. Towards the poles, where the Mts appear to terminate, there are some rounded and flattened vesicles with low electron density. There are no clearly definable "microtubule organizing centers", MTOCs, as they were described in the meiotic spindle of mouse oocytes (Szöllösi et al., 1972a; Thibault et al., 1987). Nevertheless a disc-shaped, slightly convex plaque at each pole, composed of loosely arranged filamentous material, probably represents the MTOC (fig. 9). Mitochondria, sER and different kind of membrane vesicles (smooth and clathrin coated transport vesicles) are numerous at the pole. Flattened SER vesicles often form a boundary between the felt-like material embedding the spindle (spindleplast) and the ooplasm. The cell membrane immediatelly overlaying the pole lacks microvilli and forms large folds (fig. 11). Thin filamentous material in the submembrane region may be actin although no large dome develops at this region in sheep oocytes similar to that described in mouse and hamster (Zamboni, 1972; Longo, 1985, 1987; Longo and Chen, 1986; Okada et al., 1986 ; Shalgi and Philips, 1980). In semi-thin sections the meiotic spindle is surrounded by a granular cytoplasm (fig. 10a). In lacmoid stained whole-mount preparations the "spindle-plasm » stains more intensely and has « granular » character. The meiotic division results in the female telophase chromosome set and the first polar body ( $\mathrm{Pb} \mathrm{I}$ ) (fig. 10b).

12-18 hrs later, as the chromosomes separate in the ooplasm and as the second meiotic spindle forms the chromosomes scatter randomly within the forming spindle, representing prometaphase (fig. 12a) before establishing the true Meta II spindle (figs. 12b, 13). The chromosomes in the $\mathrm{Pb}$ in contrast remain dispersed or form irregular clumps (fig. 12a). The orientation of the second

FIG. 5. - A circular bivalent stage. The NE is extensively folded and adheres to condensing chromosomes. $5,900 \times$.

FIG. 6. - Circular bivalent stage : pores are absent from the NE. The NE is, however, continuous and adhers to the condensing chromosomes and to other NE segments along large surfaces. The inner leaflet of the NE has higher electron density than the outer leaflet. At a corresponding level at the arrow, the densitometric readings were taken in direction of the arrow. $24,000 \times$

FIG. 7. - The NE is fragmented (nf) and is arranged as a shell around a central chromatin mass. The envelope fragments often remain in doublet or multiple layers. Towards the center of the nuclear territory a kinetochore is seen surrounded by a multitude of polymerized Mts. 16,000 $\times$. 


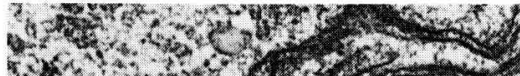
3.

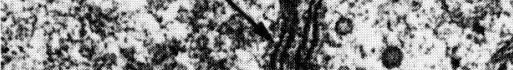

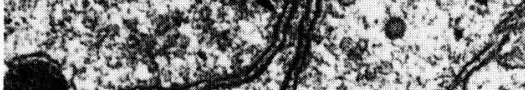

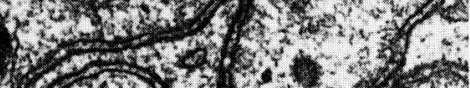
(2)

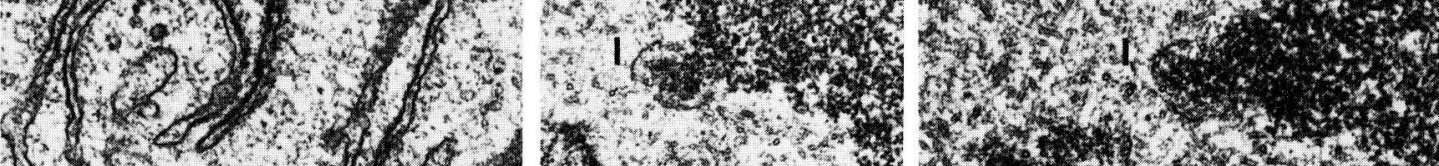

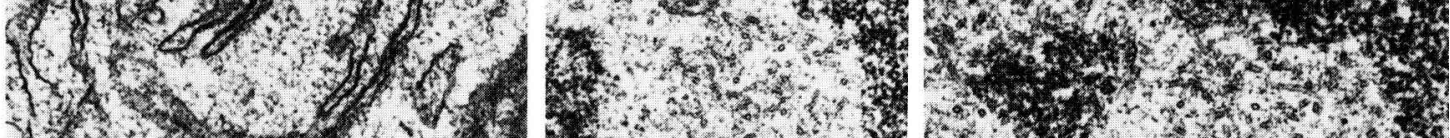

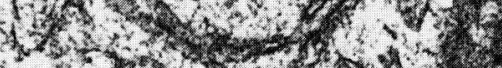
(1)

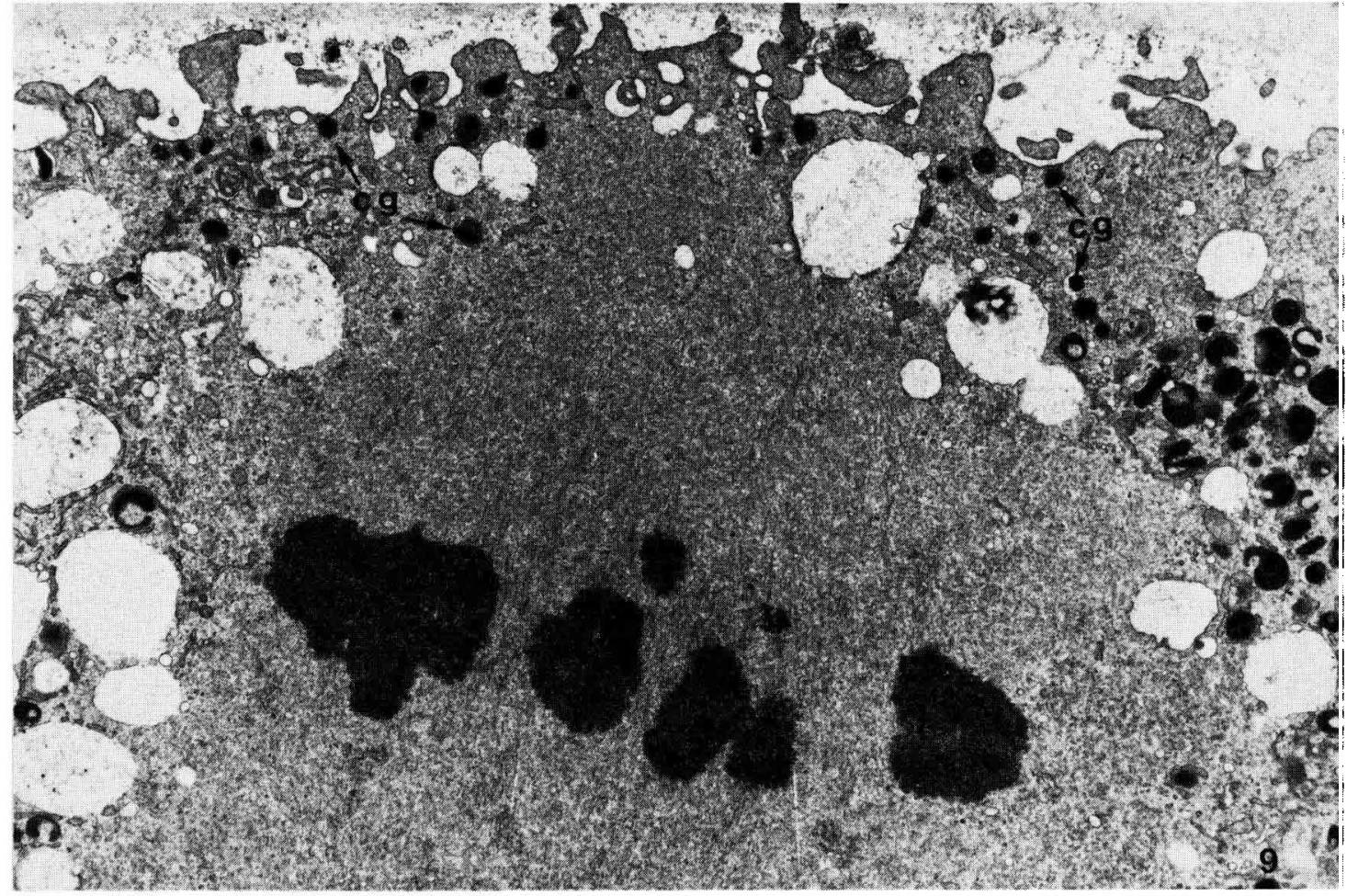

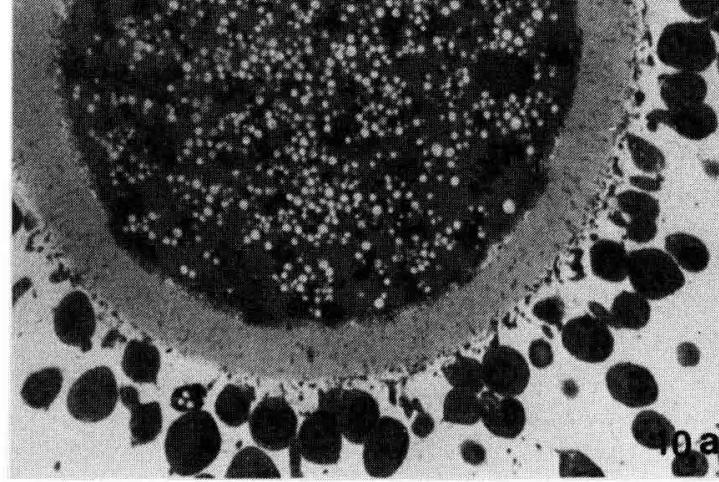


spindle is also radial in respect to the oocyte cell membrane and is also a short, barrel-shaped spindle. The newly formed spindle resembles the Meta I spindle.The main difference being the number of chromatids and the orientation of kinetochores. It must be reemphasised that both meiotic spindles of sheep oocytes are radially orientated relative to the plasma membrane as are the spindles of the pig, cow, rabbit and human oocytes (Szöllösi et al., 1986b).

\section{B. Changes within the ooplasm and between oocyte and corona-cumulus cells.}

A general description and discussion of the cell organelles in sheep oocytes is not the purpose of this article. This subject was reviewed by Cran et al. (1980). We shall describe only those organelles which undergo significant modification during cytoplasmic maturation.

The organization of the sheep oocyte cytoplasm is more easily appreciated by light microscopy of semi-thin (0.5-1 $\mu \mathrm{m})$ sections stained by methyl blue-azure method. Even if individual organelles can not be identified their uniform distribution in the ooplasm can be assessed (fig. 14). Clear vesicles, lipid droplets (both representing probably vitellin materials) and the dark blue staining cell organelles [mitochondria, Golgi complexes, cortical granules (CG), etc.] are evenly dispersed within the ooplasm. Cytoplasmic maturation affects and involves to the greatest extent the plasma membrane and the distribution of cell organelles (fig. 15).

The oocyte plasma membrane (oolemma) of freshly collected ocytes is covered by microvilli about 1-1.5 $\mu \mathrm{m}$ long and $80-100 \mathrm{~nm}$ wide. They may be either straight or curved and they abut against but do not penetrate the zona pellucida (fig. 16 ; in fig. zona is not visible). Microfilaments of $6-8 \mathrm{~nm}$ thickness occupy their center. The oolemma is frequently indented to the depth of several microns by cytoplasmic foot-processes of the corona radiata cells (fig. 17)

FIG. 8a. - The NE breaks down into shorter segments, retaining a complicated multiple layered arrangement. The envelope components separate slightly. The electron density of each of the composing membranes is similar. Densitometric recordings were made at and in the direction of the arrows $37,000 \times$

FIG. 8b, c. - Microtubules polymerize only in the center of the condensing chromatin. A (pair) kinetotochore dense layer (I) can be recognized on the chromatin; Mts polymerized in large numbers near the kinetochore but do not associate with it. Thin filamentous material forms a loose background webb among the Mts (arrow heads). Both Figs. 36,500 $\times$

FIG. 9. - The first meiotic apparatus is a short, wide barre/-shaped spindle whose axis is perpendicular to the plasma membrane. The spindle is free of formed cellular elements, excepting the spindle Mts. The cell membrane overlaying the pole region lacks microvilli and are replaced by membrane folds. The arrowheads outline the disc-shaped MTOC, a convex plaque of filamentous material. Cortical granules (CG) are present near the plasma membrane and also of some distance from it. $84,000 \mathrm{x}$.

FIG. 10a. - One half micron thick section at the light microscope level of a Meta / oocyte. A cortical region with fewer organelles is developing. Particularly the large, clear vesicles and lipid droplets are more centrad. 1,200 $\times$.

FIG. 10b. - Lacmoid stained Meta // spidle shows a more densely staining " spindle plasm " with slightly granular quality (arrowheads). The Meta II plate and the scattered, compacted chromosomes in $\mathrm{Pb}$ I stain clearly. 1,200 $\mathrm{x}$. 
$20^{3}$

20.0

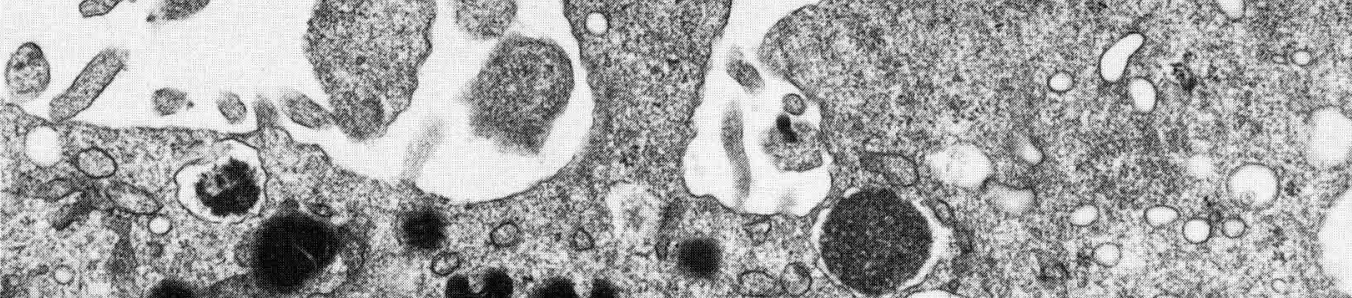

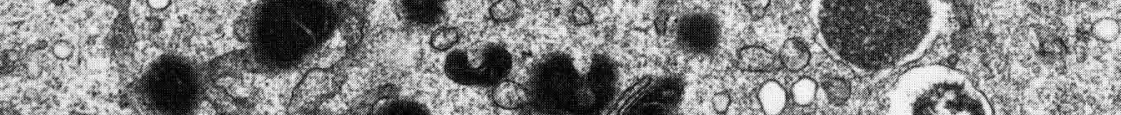

1002030 . in

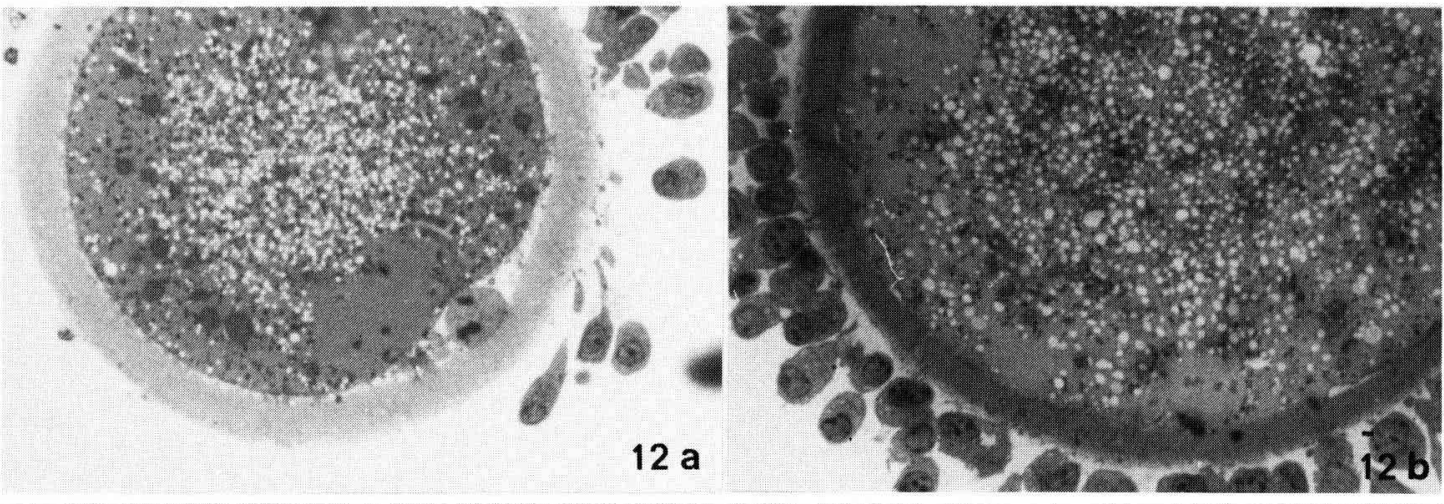

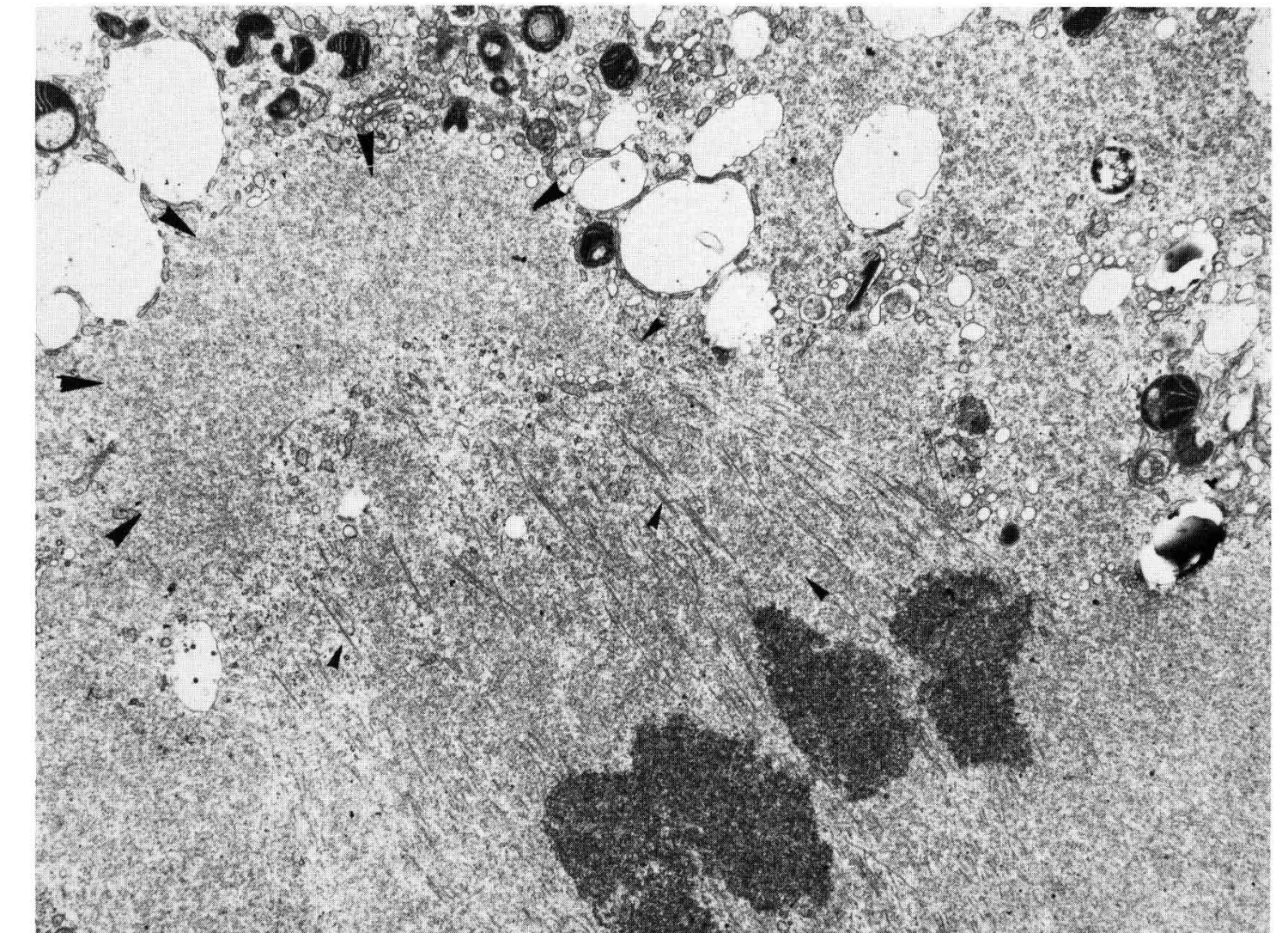

. 
(oocyte-corona cell relationship will be discussed in detail later) which represent the cell layer aligned at the outer surface of the zona. (There remains some uncertainty relating to the terminology of corona and cumulus cells. We define the corona cell layer as the one which apposes against the external surface of the zona pellucida from which narrow foot processes cross the zona and whose button-like terminations make contact with or indent the oolemma. We define corona as a « simple, cuboidal epithelium ».) The contact surfaces underlined by an electron dense layer form intermediate type junctions. One to a few gap junctions are also present. Parallele to the cell membrane microfilaments form a thin layer representing cortical actin (fig. 17). The oocyte cortex labels distinctly with fluorescent actin antibody (Le Guen, pers. com.).

Cytoplasmic organelles are uniformely distributed in follicular oocytes. Gonadotrophic hormones effect, probably indirectly, the distribution of the organelles in a 1-4 $\mu \mathrm{m}$ thick cortical layer as cytoplasmic maturation is induced. The cortex becomes poor in lipid droplets and the clear vesicles, whose nature and function remain enigmatic, will occupy the more central cytoplasm, leaving a cortex with a uniformly staining background cytoplasm in which only relatively few cell organells are located (fig. 18).

The concept of cytoplasmic maturation remains ill defined, but experimental work has demonstrated that oocytes cultured under various conditions do not result in oocytes with full developmental capacity (Thibault and Gérard, 1970 ; Thibault, 1977 ; Motlik and Fulka, 1974a, b ; 1982). The culture system employed in our experiments resulted in good fertilization rate and, following transfer of 2-8 cell stage embryos to recipient ewes, it lead to the birth of healthy lambs (Crozet et al., 1987). Thus we could employ reliably our in vitro system to study at a cellular level the oocyte transformations which in their totality mean «cytoplasmic maturation ».

The organelles present in the oocyte cortex after $5 \mathrm{~h}$ culture with $\mathrm{FSH}$ and $\mathrm{LH}$ are, in addition to the plasma membrane associated actin filaments and junctional complexes, "hooded mitochondria» (Senger and Saacke, 1970) with their associated $S E R$ vesicle, free, individual $s E R$ vesicles, often forming large aggregates, many large Golgi apparatuses, some ribosome studded ER and clusters of cortical granules. The CG are in various stages of maturation, that is, condensation (fig. 19). CGs are essentially in large aggregates and only few are found individually along the plasma membrane.

FIG. 11. - Thin filaments (approximately $6 \mathrm{~nm}$ in diameter) pervade all of the large folds and the cortical area overlaying the Meta / spindle. 27,000 $\times$

FIG. 12a. - Prometaphase // is rarely observed. The female telophase I chromosomes are scattered in an organelle free cytoplasmic domain. 1,200 $\times$.

FIG. 12b. - Meta // spindle forms a/so peripherally and with a perpendicular orientation of the spind/e axis to the plasma membrane. 1,200 $\times$.

FIG. 13. - Meta // spindle is a short, barre/-shaped structure. The polar area is a slightly curved disc of filamentous material (large arrow heads). It represents an MTOC. Similar material is found also between the Mt bundles of the spindle apparatus (small arrow heads). 14,000 $\times$. 


\section{The corona-oocyte junctional complexes.}

The corona cell-oocyte relationship is of utmost importance as what regards the structure and function of oocyte cortex because, during the oocyte's growth phase many essential elements enter the oocyte by the means of the corona cell foot processes (Wassarman and Letourneau, 1976; Eppig, 1979; Moor et al., 1980 ; Heller et al., 1981). The corona cells are orthogonal cells with one to few narrow foot processes (fig. 20) which penetrate and cross the zona pellucida. They terminate in a button-like, bulbous enlargement which in the sheep indents the oocyte to the depth of several microns. The processes within the zona measure $15-25 \mathrm{~nm}$ in diameter; they contain thin filaments which are positive for actin by immunocytochemical techniques (Le Guen, pers. com.). Within the terminal enlargements mitochondria, membranous elements and microfilaments may be present (fig. 21). Close to the nucleus are $10 \mathrm{~nm}$ thick fibers which may represent intermediate filaments. An electron dense material lines much of the apposing membranes of heterologous cells, forming plaques similar to intermediate junctions (Zamboni, 1970, 1972). Small, disc-shaped gap junctions are incorporated between the apposing cell membranes, (fig. 22) which make electrotonic and molecular exchanges and continuity possible between the two different cell types (Gilula et al., 1978; Anderson, 1977; Anderson and Albertini, 1976; Szölösi, 1978). Both types of junctional complexes bind and couple neighbouring corona cells and also with cumulus cells. In contrast to the corona cell-oocyte junctions, the gap junctions between follicle cells may be very long and may not be integrated between segments of intermediate junctions.

Following 5-6 hours culture the oocyte deforms; it looses its sphericity and develops a large number of conical protuberances (fig. 23a, b). On closer study the protuberances are formed at sites of corona cell foot process incertions. At some incertions the foot process termini still indent slightly the oocyte cortex while at others the contact between the two cells became superficial (fig. 24). At

FIG. 14. - Semi-thin section of GV stage oocyte cultured for $4.5 \mathrm{~h}$ with gonadotrophins. NE folds develop close to the plasma membrane and chromatin condenses along the NE. Cell organelle redistribution is not extensive. The corona radiata cells (arrows) are cuboidal and show slight expansion. 1,200 $\times$

FIG. 15. - An overview of the sheep oocyte cortex : microvilli cover the oocyte surface uniformely All types of cell organelles are dispersed through out. 8,300 $\times$.

FIG. 16. - The oocyte membrane microvilli are either straight or bent. They occupy the perivitelline space but do not penetrate the zona (the zona is not visible). A bundle of thin filaments (arrows) is located within the microvilli. $30,000 \times$

FIG. 17. - Corona cell foot processes indent the oocyte surface. Intermediate (1) and gap junctions (arrow head) form between the heterologous cell types. Actin filaments are in the cortex in the proximity of the foot process termini. $28,000 \times$.

FIG. 18. - Few formed cell organelles remain close to the cortex after 7-10 h exposure to gonadotrophins. Cortical granules (arrows) move towards the plasma membrane ; few mitochondria and small Golgi units are to be found within a 2-5 $\mu \mathrm{m}$ thick cortical cytoplasmic layer. Few corona cell termini are superficially adhering to the oocyte. $30,000 \times$

FIG. 19. - Cortical granules of different maturation stages accumulate into aggregates of different sizes. $25,000 \times$ 
the junctions electron dense plaques are still present along the contacting plasma membrane surfaces of heterologous cells. Small gap junctions are present in regions of the electron dense plaques. At other junctions the foot process is exteriorized retaining, however, the junctional complexes. Long cytoplasmic processes of the oocyte (fig. 24), whose diameter is larger than that of microvilli, surround the bulbous corona cell foot processes. The cell membrane looses microvilli over large areas but local «tufts» are present (fig. 25). The oocyte surface rearrangements apparently are due to contractile forces exerted within the corona cell foot processes and the strength of the junctional attachment plaques. The corona cell bodies elongate in an ax radial to the oocyte and disperse. The intercellular junctions and adhesion is significantly reduced (Larsen et al., 1986).

Expansion of the corona-cumulus layers consists of changing their shape. The cells become oblong, tapering towards the oocyte. The width of the corona cells in particular, is reduced. The cell becomes oblong and the nucleus ovoid. The tapering of the cell starts at the level of the nucleus forming a long conical process towards the oocyte. Close to the nucleus and in the tapering part of the cell a large mass of filaments of the intermediate filament range are found while in the much narrower foot processes towards and within the zona thinner filaments, measuring about $6 \mathrm{~nm}$ in diameter are present. The dimension of the filaments suggest that they are $f$-actin. The intercellular junctions and adhesions are significantly reduced in extent (Larsen et al., 1986), but frequently few cells remain together, forming small groups. At the level of the zona some of the foot processes come in contact, at which points an electron dense material deposits, representing newly forming adhesion sites. Similar adhesions are observed also between corona cell foot processes in the perivitelline space.

The 7.5 hrs culture sample represents also from the point of view of presence or absence of junctional complexes between oocyte and follicle cells a particular interest. The cell to cell relationships can be divided into three groupes : a) the junctions are present at the protuberances (fig. 23) of the oocyte; b) junctional complexes are present but making contact only superficially with regressing conical protuberances; few free foot process termini are present (fig. 24). No sign

FIG. 20. - Corona radiata cel/s are orthogonal cells in close proximity to the zona pellucida. From these cells narrow foot processes traverse the zona and form junctional complexes with the oocyte surface. $12,500 \times$

FIG. 21. - In the enlarged corona cell terminus mitochondria, multivesiculate bodies and microfilaments of various sizes may be present. $20,000 \times$

FIG. 22. - Small gap junctions (arrow heads) are intercalated between segments of the intermediate junctions (1). The shown terminus is a superficial adhesion site. 65,000 $\times$

FIG. 23a, b. - The oocyte surface is deformed and conical protuberances develop at each corona cell foot processes (arrow). a. 11,000 × ; b. 8,200 $\times$.

FIG. 24. - The adhesion sites between corona cell foot processes and oocyte become superficial 5-6 h after hormone exposure. The intermediate junction are clearly still present. Oocyte cell process, larger than microvilli project around the bulbous corona cell terminus. 44,000 $\times$.

FIG. 25. - After 6-8h culture most of the foot processes loose their association with the oocyte. The oocyte regains its spherical form. Only small "tufts» of microvilli remain on the oocyte surface. $5,500 \times$. 

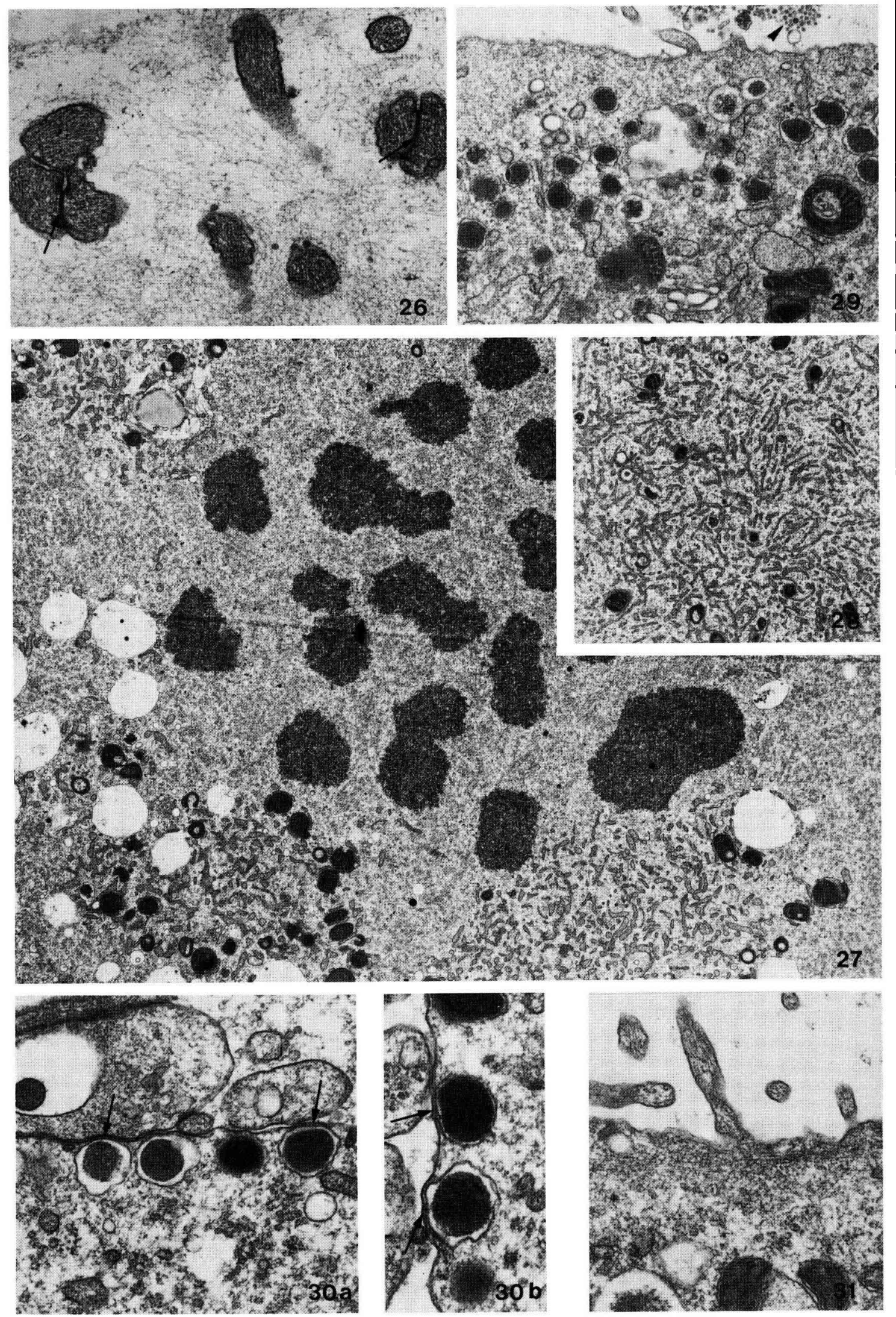
for the junctional plaque remains; $c)$ the oocyte returnes to its spherical shape : junctional complexes no longer exist. Corona cell foot processes terminate freely in the perivitelline space (fig. 21).

The three different kinds of corona cell-oocyte junctional relationships correspond to the three groups into which the nuclear structure was divided after $7.5 \mathrm{~h}$ of culture and demonstrates that GVBD and termination of follicle cell-oocyte association coincide. These structural observations reopen the controversy in regard to the time at which molecular passage and exchange between follicle cells and oocyte still takes place (Moor et al., 1980; Moor and Gandolfi, 1987; Eppig, 1982). Our observations suggest that reorganization of junctional complexes and reduction of intercellular communication coincide with GVBD.

Most corona cell foot processes are fully withdrawn or broken off, which fragments degenerate after the cell junctions are interrupted. One expression of degeneration is the appearance of many small vesicles (fig. 29) on the surface of the foot processes which remain in place. Some cell processes break and autolytic vesicles may develop in them. In the perivitelline space some foot process termini remain in Meta II oocytes. Between the foot processes remaining in place junctional complexes form anew either at the level they reach the periphery of the zona or within the perivitelline space (fig. 26)

\section{The Golgi apparatus and the cortical granules.}

The changes undergone by the Golgi complex and cortical granule distribution undergo after initiation of the maturation events will be discussed together.

The Golgi apparatus is very extensively developed in sheep oocytes recovered from antral follicles. Their presence around the GV was mentioned above. When Meta I is formed in place of the Golgi systems surrounding the GV large smooth ER complexes form. They have a flocculent content. They are surrounded and also intermingle with mitochondria. The localization of the sER complex suggests that the Golgi system, usually present in the proximity of the GV was either

FIG. 26. - The expanding cumulus-corona cell's narrow foot processes form at the surface of the zona pellucida a new type of junctional complex (arrows). Their nature is not yet identified. $38,500 \times$

FIG. 27. - At Meta // the metaphase plate is surrounded by four large, sER membrane complexes (the fourth was in the place of fig. 28). The lumina of the sER vesicles is filled by a flocculent material of moderate electron density. There is no sign of any Golgi system in the proximity of the spindle. $8,000 \times$

FIG. 28. - An other example of the flattened, smooth ER vesicle system. 11,000 $\times$.

FIG. 29. - At the beginning of culture several c/usters of CGs are found within the sheep oocyte cortex. They are of different condensation (maturation) stages. $24,000 \times$

FIG. 30a, b. - In Meta // oocytes the CGs are located very close to the cytoplasmic surface of the plasma membrane. The compaction of the granule contents is variable. The mature granules are of uniform electron density envelopped by a closely adhering limiting membrane. The other CGs, with unevenly dense granules, are in other phases of compaction. An electron lucent space surrounds them and a limiting undulatory membrane. At the arrows, see a row of "spokes" whose role probably is to affix the granules to the cell membrane. a. $40,000 \times ;$ b. $50,000 \times$.

FIG. 31. - After GVBD thin filaments (probably actin) remain only in limited areas paralle/ to the cell membrane. $15,500 \times$ 

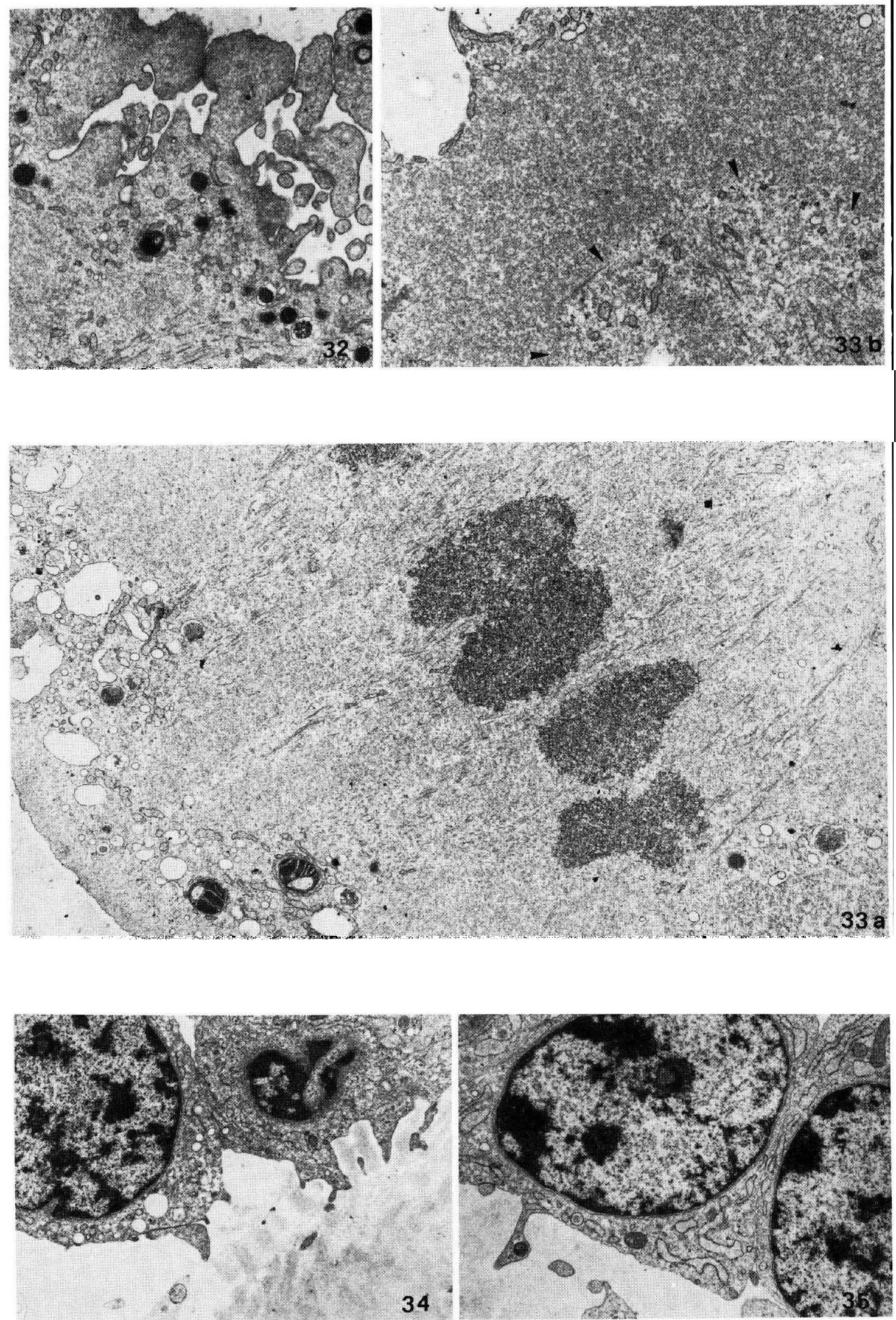
transformed into the ER system or replaced by it (fig. 27,28 ). Along the entire oocyte surface, in close intervals, a large Golgi unit is located. It develops near the attachment point of every corona cell foot process indicating that the Golgi apparatus probably plays a role in processing of the materials transferred from the follicular fluid into the oocyte.

Cortical granules (CG) are formed usually by the Golgi units with peripheral location although, more rarely some are formed also by the more centrally localized units. There may be specialized subpopulations of Golgi complexes in this large cell, the oocyte. The function of one of these subpopulations, which is morphologically clearly definable is the formation of the necessary number of CGs while most other functions remain to be determined. At the beginning of culture a number of CG clusters are present in the oocyte cortex (fig. 29) ; the granule's size and degree of compaction of their contents vary; some granules are fully compact while in others the filamentous content is still recognizable. The bounding membrane of the latter is slightly undulatory and a thin, electron-lucent space separates it from its content (fig. 30). Granule distribution along the oocyte plasma membrane is initiated only after oocyte has been in culture for several hours. CG clusters still exist after 5-6 h in culture with gonadotrophins. Only rarely are some of the CGs moved peripherally at this time. Dispersion along the cortex occurs after $7 \mathrm{~h}$ in culture but the CGs are yet of irregular distance from the plasma membrane. Some granules are relocated when the NE becomes folded as the circular bivalent stage is formed (fig. 5,6). At the time of GVBD most of the granule complexes are distributed and only a few granules remain together in small clusters. A fully peripherally located cortical granule layer is established at Meta I spindle formation 12-16 h of culture but is still of irregular distance from the plasma membrane. The thin, filamentous actin layer parallel to the plasma membrane which would interfere with the CGs approximation to the periphery, is no longer present, or is seen only locally (fig. 31). At the time of first polar body abstriction many CGs are incorporated into the PB I cytoplasm (fig. 32). PB I usually fragments in the sheep and many fragments contain CGs. As soon as the granules approach the plasma membrane, reaching their final positions, small spokes anchor them to its inner surface of the plasma membrane. When Meta II spindle is formed CGs are nearly totally absent from the region where the spindle pole apposes against the plasma membrane (fig. 33a, b).

FIG. 32. - Cortical granules are incorporated into $\mathrm{Pbl}$ during its abstriction and into several cytoplasmic fragments formed. $15,000 \times$.

FIG. 33a. - Meta /I spindle is also a short, wide barrel-shaped spindle. The spindle axis is perpendicularly oriented to the plasma membrane. At the peripheral pole vesicular elements, mitochondria and a few CGs are seen. 15,500 $\times$.

FIG. 33b. - At both of the spind/e poles a curved plate is located (arrow heads) which is composed of thin filamentous elements. It probably corresponds to the MTOC. 22,000 $\times$.

FIG. 34. - Cumulus expansion is partial after $6 \mathrm{~h}$ culture in the full culture medium, followed by $18 \mathrm{~h}$ in medium TC 199-H containing only $20 \%$ fetal bovine calf serum. 8,500 $\times$

FIG. 35. - No corona-cumulus cell expansion occurs during $24 \mathrm{~h}$ culture in medium without hormones. The cells remain orthogonal. $9,000 \times$. 
The central part of the oocyte cytoplasm is occupied by clear vesicles and lipid droplets (fig. 10b, 11, 12). Among these inert cytoplasmic organelles, representing most likely vitelline materials, islets of metabolically active cell organelles e.i. Golgi complexes, hooded mitochondria, rough and smooth endoplasmic reticulum and free polysome clusters are present. Morphological changes may occur in these cell organelles during the hormone induced meiotic maturation but other than their possible displacement, are very difficult to record.

\section{E. Maturation of ovarian oocytes under experimental conditions.}

It was of interest to determine if an other mammalian embryo than the mouse can develop to term if matured and fertilized in vitro in absence of gonadotrophins or does removal of the "maturation inhibiting factor(s) " assure normal development? Is the exposure to gonadotrophic hormones an absolute requirement for the production of fertilizable oocytes and normal embryonic development in most mammalian species? If not, are shorter incubation times with hormones sufficient to initiate and complete the maturation events ? In case shorter periods of exposure did initiate maturation is it partial or full ? Is the speed of maturation comparable with that of oocytes exposed throughout the $24 \mathrm{hr}$ maturation period to the same hormone levels?

\section{TABLE 1}

Meiotic stages of sheep oocyte after $24 \mathrm{~h}$ culture.

\begin{tabular}{lcccr}
\hline & & & & \\
& No. oocytes & HO & H.HO & HO- \\
Stage & No. exp. & 28 & 14 & 21 \\
& & 5 & 3 & 4 \\
\hline Metaphase II & $26(93 \%)$ & $6(43 \%)$ & $5(24 \%)$ \\
Prometaphase II & $2(7 \%)$ & $8(57 \%)$ & $2(9.5 \%)$ \\
Telophase & - & - & $5(24 \%)$ \\
Metaphase I & - & - & $3(14 \%)$ \\
Prometaphase I & - & - & $5(24 \%)$ \\
G.V. & - & $1(4.5 \%)$ & \\
\hline
\end{tabular}

TABLE 2

Rate of sperm penetration $17 \mathrm{~h}$ after insemination.

\begin{tabular}{llcc}
\hline & $\mathrm{HO}+$ & $6 \mathrm{H} . \mathrm{HO}+$ & $\mathrm{HO}-$ \\
\hline $\begin{array}{llc}\text { No. } \\
\text { No. penetrated }\end{array}$ & 46 & 31 & 26 \\
$\begin{array}{l}\text { Rate of pronucleus } \\
\text { formation (\%) }\end{array}$ & 21 & 15 & 3 \\
\hline
\end{tabular}


The results of a small series of experiments in which formation of bipronucleate zygote, abstriction of $\mathrm{Pb}$ II and recognition of the sperm tail were accepted as fertilization criteria, suggest that maturation of sheep oocytes is very irregular, even though possible, when cultured without gonadotrophic hormones for $24 \mathrm{~h}$ (table 1). In vitro fertilization and apparently normal pronuclear development, is also possible but at a low rate (11.5\%, table 2 ). Only a few oocytes ( 3 out of 26 ) were penetrated by spermatozoa and gave normally appearing pronucleate stages. At the end of culture period very few oocytes blocked with GV are found while about one third was in Meta I and Meta II respectively or any of the intermediate meiotic stages. When, however, oocyte cultures were terminated after an additional $17 \mathrm{~h}$ following insemination, all of them advanced to Meta II. Thus without hormone support oocyte development is severly delayed. The low rate of bipronucleate zygote formation bears witness of the importance of the supplementation of the culture medium with purified gonadotrophins $(10 \mu \mathrm{g} / \mathrm{ml}$ of each, FSH and LH). Oocytes matured with hormones and otherwise strictly identical culture conditions lead to $46 \%$ bipronucleate stages (table 2 ).

The sensitivity of COCs to shorter than the $24 \mathrm{~h}$ exposure in culture to purified gonadotrophins was tested by morphological criteria and by a biological test : fertilizability ( 2 pronuclei stage, limit set arbitrarily for these experiments). Oocytes exposed $6 \mathrm{~h}$ and completing the $24 \mathrm{~h}$ of culture time without hormones, gave fully mature oocytes. Tables I and II show that in our, admittedly short and preliminary experimental series, $6 \mathrm{~h}$ exposure gave 100 and $48 \%$ maturation and fertilization respectively while only $11.5 \%$ had two pronuclei without hormones. The cumulus expansion was extensive when COCs were exposed for $24 \mathrm{~h}$ to gonadotrophins while only partial after $6 \mathrm{~h}$ in full medium (fig. 34). Cumulus expansion is not perceptible when no hormones were added to the medium (fig. 35).

The cumulus and corona cells morphological response is of little value in making predictions as to the success or failure of oocyte nuclear maturation. It can be said that when the expansion of the cumulus was great the oocyte usually completed its maturation but no prediction can be made as to the state of maturation when cumulus expansion is partial or, apparently, not at all. A slight expansion of the corona cells does occur. The elongate and a short cone develops towards the zona. The fertilization rates of 6 and $24 \mathrm{~h}$ culture with hormone containing media were identical. In contrast the low fertilization success rate, achieved of oocytes in compact cumuluses, when no hormones were added, the nuclear maturation state reached was very heterogeneous, giving $24 \%$ Meta II oocytes while the remaining oocytes were found in stages between GV and prometaphase II (table I).

Exposure of COCs for $24 \mathrm{~h}$ to the medium with $\mathrm{FSH}$ and $\mathrm{LH}$ resulted in a very high $93 \%$ maturation and $46 \%$ fertilization rates. We endeavor in enlarging the series and numbers within each series. The results show a clear cut tendency for the positive role gonadotrophic hormones play in achieving full meiotic maturation of cumulus enclosed sheep oocytes and in assuring the normal developmental sequence after insemination. Expansion of these studies will lead us to a better comprehension of meiotic maturation. 


\section{Discussion.}

The reported experimental series on in vitro culture of sheep oocytes demonstrate that the meiotic maturation can regularly be induced and that this induction requires the presence of both gonadotrophic hormones, estradiol-17 $\beta$ and mural granulosa cells. Spontaneous maturation occurs in sheep (close to $60 \%$ ) if GVBD is accepted as criterion for maturation but only few normal zygotes with two pronuclei resulted (11.5\%) when fertilized in vitro. Low developmental capacity is general in mammalian oocytes matured in vitro (Thibault et al., 1975).

The first six hours of culture represents the critical period during which the gonadotrophic hormones must be present and active to initiate full meiotic maturation. The synthesis of the $47 \mathrm{kD}$ protein, whose prior synthesis appears to be of critical importance for GVBD (Moor and Gandolfi, 1987) must take place during this period. The first six hours correspond, however, to the " calm " period, when morphologically minor changes take place. In contrast, the major structural transformations occur during the second, metabolically calmer phase. That the significant physiological events leading to meiotic maturation take place whithin a relatively short period of time can be taken adventage of, in finer analyses of the sequence of physiological and morphological changes which set in motion the cascade of events in the production of oocytes with full developmental capacity.

The rate of meiotic maturation in vitro (22-24 h) in presence of gonadotrophins is identical to the time required to reach Meta II oocytes at ovulation after detection of estrus. The beginning of culture in the complete medium may thus be taken as «point zero» for studies of the physiological and celtular events involved in oocyte maturation.

\section{A. Modifications of the nucleus}

In antral sheep follicules the oocyte nucleus, the germinal vesicle (GV), is located peripherally in contrast to the murine species. The chromatin is fully decondensed and only very small, local chromatin condensations exist along the NE. The cytoplasmic organelles are uniformly distributed at the same time. In the mouse oocyte GVBD takes place centrally and the Metal spindle moves peripherally (Szöllösi et al., 1972a). In most other mammals, as the case in point, the sheep oocyte, the GV lies already peripherally in the arrested dictyate stage. The GV flattens against the plasma membrane leaving a very narrow cytoplasmic layer between the two membrane complexes over a large surface area during the first few hours of culture. The mechanism involved in the flattening process is being currently analysed in our culture system. Its physiological role is not known. Even if no direct contact between the NE and plasma membrane is demonstrable, the transfer of some information from the corona cells directly or from the follicular fluid appears to be a possibility. It may relate to the initiation of NE folding and/or chromosome condensation, an important next step. Morphologically neither of the cytoskeletal systems appear to be involved in the flattening process. This process was already discribed as a step in meiotic maturation in oocytes of the domestic pig (Gérard et al., 1979).

The NE and chromatin are the first cell structures to show morphological changes after initiation of culture : large, finger-like infoldings form at the side of 
the plasma membrane, while towards the cytoplasm it forms a smooth hemisphere. The NE structure itself does not change : the width of the perinuclear space and nuclear pore density remain the same. Chromosome condensations are initiated along the NE but particularly in association with the NE folds. Chromosome condensation is induced in our culture system the force of which is transferred on to the NE segments by its attachment to it and causes its deformation. Chromosome attachment to the NE has been particularly clearly demonstrated in meiotic cells (Moëns, 1969; Cummings and Okada, 1970; Church, 1977). Franke and collaborators (1981) demonstrated the existence of "thread connections » between chromatin and NE. Threads may link chromatin also to the NE stabilizing the protein subunits of the pore complex. The molecular mechanisms which control condensation are not yet understood in general, even less its dependence on gonadotrophin action of this process in the $G V$. Chromosome condensation and NE folding are continued until a "star-shaped " nucleus, the circular bivalent stage, an extreme, a terminal point of the initiated NE folding is reached. The NE adheres closely to the chromosomes where ever they are in contact. The inner leaflets of the "surplus » envelope portions containing lamins (Maul and Schatten, 1986; Rime et al., 1987) adhere to each other, forming quadruple membranes. Both of the centrally placed membranes are the inner leaflets of the GV envelope and their higher electron density (fig. 6) is probably due to the presence of lamins. Quadruple membranes are characteristically found in pro-metaphase stages, in both, meiosis and mitosis (Szöllösi et al., 1972a, b). The term: "paired cisternae" has also been employed for the description of similar membrane portions near chromatin (Franke et al., 1981).

The possible role of chromatin condensation in the extensive NE folding in the circular bivalent stage in the rabbit was already presented (Szöllösi, 1975). The NE becomes folded to a similar degree during meiotic maturation in vivo and in vitro in cow oocytes (Hyttel, 1987 ; Hyttel et al., 1986a, 1986b, 1986c). GVBD follows the formation of this highly folded nucleus.

During the folding of the NE the nuclear pores disassemble leaving no recognizable trace of their previous location. The proteins forming the pore annulus are attached in some way to the NE, that they can separate easily. Chromosome condensation may have altered thread connections between chromatin and pore, thus altering also the stability of the pore complexes. The disappearance of the nuclear pores may be due to the changes made in chromosome-NE (pore) relationship.

Recently the pore complex proteins have been isolated and are currently being characterized (Snow et al., 1987). The membrane mobility must be large enough to reestablish its apparent continuity. These observations support the hypothesis that the pore structures are loosely attached elements of the NE (Unwin and Milligen, 1982) and that it is not built symmetrically into the NE. The first of many events in preparation for NE break down is the disengagement of the pore complexes from the membrane pair and is followed by the dispersion of the phosphorylated lamins but which occurs after GVBD. The dissociation of lamins from the NE does not seem to be a prerequisite for NE breakdown. Long NE segments stain with fluorescent lamin antibodies during GVBD (Rime et al., 
1987). The higher peaks given by densitometry of the inner NE leaflet in GV and the apposed surfaces in quadruple membranes are due most likely to the presence of lamins. Quadruple membrane segments may also form by the apposition of flattened smooth ER-like membrane vesicles along, usually, the inner NE leaflet (Calarco et al., 1972 ; Szöllösi et al., 1986a). The apposing membrane surfaces show also higher electron densities.

Microtubules ( $\mathrm{mt}$ ) are rarely observed around the GV of sheep oocyte and are certainly not present in the finger-like cytoplasmic chanels of the folding NE. This observation, also made during meiotic maturation of rabbit and calf oocytes (Szöllösi, 1975) while a bundle of mts is found within the cytoplasmic core of the indenting NE in mouse oocytes each emanating from an MTOC which are disposed around the GV (Calarco et al., 1972; Szöllösi et al., 1972a). When breaks become evident in the NE mts polymerise in massive amounts but with random orientation within the nuclear sphere, which is still deliniated by remnants of the NE. These observations are congruous with the immunocytological observations of tubuline and MAP1 distribution during GVBD. The former is limited to the cytoplasm and the latter to the nucleus before nuclear rupture. Multiple MTOCs, with aster-like elements, are formed as GVBD occurs (Rime et al., 1987, 1988). Mts do not associate with the forming kinetochores even though they are near to them in large numbers. The kinetochores must apparently " mature " first after NE breakdown before they become competent to attach to mt-s. A similar interpretation was given to kinetochores formed on prematurely condensed chromosomes in oocyte-thymocyte cell hybrids (Szöllösi et al., 1986a). In sheep oocytes MTOCs were not as clearly recognizable structures during GVBD as in mouse oocytes.

Meiotic spindles I and II are both barrel-shaped and centrioles were never found at either spindle pole. It would be premature to generalize and claim categorically that they were acentriolar, similar to the mouse (Szöllösi et al., 1972a) because no serial reconstruction was yet made in the sheep. The number of studied samples is still relatively low. The fact, that thus far, no centrioles were found at spindle poles of sheep oocytes in some of which several long series were in fact examined, permits us to assume that they also lack centrioles. Both spindles are short and wide barrels and their axes (a line passing through both spindle poles) are radially oriented to the plasma membrane. The orientation of meiotic spindles of most mammals studied, with exception of the most studied rodents, are radial (Szöllösi et al., 1986b). The entire spindle is immersed in a fine felt-like, filamentous « spindleplast » from which most organelles are absent, with the exception of a few small clear vesicles. At each spindle pole a filamentous material of slightly different consistancy forms a curved plaque, representing probably the MTOCs, as judged by structural and organisational criteria. That the «spindleplast» may contain related structural proteins throughout the spindle was sugested by a recent report employing a spontaneously formed anticentrosomal antiserum, 5051, (Calarco-Gillam et al., 1983) which showed on frozen sections of mouse oocytes a uniform staining over the entire spindle (Rime ; 1987) instead of a specific localisation at the poles and MTOC (Calarco-Gillam et al., 1983 ; Maro et al., 1985 ; Schatten et al., 1986) as reported by other studies 
employing the same antiserum on mouse egg « wholemount » preparations. Only further studies with new antisera, or specific anticentrosomal antibodies will be able to resolve this controversy.

One pole of both meiotic spindles lies within a micrometer of the plasma membrane, which remains undulatory and a thin layer of filaments, probably actin, is associated with it. This cortical layer is similar to the polar region overlying the first meiotic spindle of hamster oocytes (Okada et al., 1986) which does not form the smooth dome-like actin reinforced protuberance associated with the second meiotic spindle, which is tangentially oriented in rodent oocytes. This differentiated oocyte cortical segment thus seems to be the consequence of a different kind of interaction between the tangentially oriented spindle and the oocyte plasma membrane adjacent to it.

\section{B. Ooplasmic components}

The distribution of cytoplasmic organelles changes significantly a few hours after the culture of COCs with the complete, hormone containing medium. At time 0 , at the time of their collection, cell organelles are uniformely distributed in the ooplasm as the light microscope preparations bear witness (fig. 1, 10b, 12, 13, 14). The membrane bounded clear vesicles, lipid droplets and the darkly staining mitochondria can be espetially clearly visualised. The two former organelles, both of which can be considered as part of the vitellus, are nearly completely centrally concentrated after 4-5 h of culture, leaving behined a clear cortical cytoplasmic band of 1-4 $\mu \mathrm{m}$ thickness. In pig and human oocytes a cortical cytoplasmic layer of similar dimensions was reported (Gérard et al., 1979; Kruip et al., 1983; Szöllösi and Gérard, 1983 ; Hytell et al., 1986a, b, c ; 1987 ; Szöllösi et al., 1986b).

With electron microscopy, the distribution of the cell organelles can be analysed more finely. In the cortex of sheep oocytes the Golgi complex is extensive. Its presence near the corona cell incertions will be discussed later in greater detail. At the onset of culture, cortical granules (CG) in the process of formation in the Golgi complexes, are released on their trans-face and concentrated in condensing vacuoles, following the pattern classically described for the formation of secretory granules (Farquhar and Palade, 1981). The "two populations », the light and dark CGs, represent granules at different maturation stages, even if at the time of ovulation both " types " of granules coexist near the plasma membrane (Cran and Cheng, 1985). They are stored in the cortex as clusters, the individual granules being in different condensation states. Their formation is still in process and will remain so, until Metaphase I of meiosis. Their peripheral migration and distribution in a random pattern starts with the interruption of the junctional complexes between corona cells and oocytes after approximatelly $7 \mathrm{~h}$ of culture. In the mouse oocyte CG formation is delayed even until later, lasting until the time of ovulation and even there after (Zamboni, 1970, 1972). The CG distribution is at least a two-step event : a. distribution of the CG into a more or less single layer, but they remain of variable distance from the plasma membrane (a period lasting until about Metaphase I); b. the CGs approach their final position, approximately of $10 \mathrm{~nm}$ distance. Between the limiting membrane of $C G$ and the plasma membrane a row of spokes with regular 
periodicity develops, serving apparently as anchors. In centrifuged preovulatory oocytes (pig, sheep and cow) the CGs remained close to the cell membrane indicating a firm anchorage of the CGs. In immature cow oocytes many CGs were centrally displaced by the centrifugal force (Cran, 1987). The spokes could possibly also serve the facilitation of fusion between the two membranes at time of activation. The "spokes" assure the attainment of the optimal distance to permit fusion of the two participating membranes. A « septate-like " structure was reported between adhering cell membranes just prior to induction of fusion to form cell hybrides (Szöllösi et al., 1986a).

\section{The changing cumulus (corona) - oocyte relationships.}

From the moment of follicle formation direct contact between the follicle cells and oocyte is established. The cells surrounding the oocyte may play a structural or a metabolic supporting role. The follicle cells provide certainly much more than a niche for the oocyte; they supply nutrients during the oocytes' growth phase until nearly the moment of ovulation from small metabolites to amino acids and nucleocides (Eppig, 1982 ; Moor et al., 1980). The presence of gap junctions was demonstrated by diffusion of injected fluorescein between oocytes and corona cells (Gilula et al., 1978) and by morphological means (Anderson, 1977 ; Anderson and Albertini, 1976; Szöllösi et al., 1978). The follicle cell-oocyte contact is different in different mammals. In the ruminants, every corona cell develops a foot process with a large bulbous terminus which deeply indents the oocyte plasma membrane (Hyttel et al., 1986a ; Szöllösi, 1975).

The morphological detail of junctional complexes differ between the heterologous and homologous cells. In the former case the structural elements, the electron dense plaques represent the dominant component, while the gap junctions are small and become intercalated between segments of the structural units. Judging from the transfer rate of labelled compounds (Moor et al., 1980 ; Motlik et al., 1986; Sherizly et al., 1987), the small gap junctions function efficiently, inspite of their size. Already the localization of the large Golgi apparatuses in the proximity of every foot process terminus suggests their role in potential bidirectional molecular transfer (Moricard and Moricard, 1975). In contrast, the gap junctions between cumulus cells may cover several square microns and are the sole component of these junctions. Different morphological solutions may have evolved because the respective roles they play were also substantially different.

Expansion of cumulus-corona cells implies a drastic change in shape; the cuboidal cell, with a spherical nucleus, coupled by permeable junctions to its sister cells and to the oocyte, so that the entire COC functions as a physiological syncytium, is transformed into a relatively isolated collumnar-conical cell. This cell is clearly polarized structurally and probably also a functionally. Following stimulation by $\mathrm{FSH}$ they secrete hyaluronic acid changing radically their extracellular environment. The significance of these changes remain to be clarified. It might be related, however, to the event to follow : ovulation.

During the corona cell elongation 8-12 h of culture, new contact relationships are established between the foot processes of neighbouring cells at the zona 
surface and whithin the perivitelline space. At the same time the oocyte-corona cell junctions decrease in number and are partially or totally eliminated between 7-8 $\mathrm{h}$ after culture with gonadotrophins. These observations indicate that the junctions between the homologous and heterologous cells are qualitatively different and that different signals may exist for their maintenance and interruption. The interruption coincides with GVBD. In rabbit, pig and cow the corona cell-oocyte junctions follow a similar developmental pattern (Szöllösi, 1975; Motlik et al., 1986 ; Hyttel et al., 1986a). If gap junctions are always necessary for transfering amino acids, nucleosides and choline into the oocyte, their transfer should be stopped at this time. Thus the transfer of intracellular markers if there are any at all close to the time of ovulation (Moor et al., 1980) cannot take place by permeable junctions and an other mechanism must be sought. In rat oocytes intercellular communication between oocyte and cumulus ends also at GVBD (Sherizly et al., 1987).

The cumulus-corona cell expansion can not be used as a reliable marker for judging the state of the oocyte maturation. In sheep we find that when the cumulus has expanded the oocyte maturation has taken place, but the opposite can not be stated, that the oocyte had not reached Metall stage when the cumulus dispersion is only partially or had not occurred at all. Similar conclusions were drawn in earlier studies on oocyte maturation of the domestic pig (Gérard et al., 1979).

\section{Experimental series.}

Our experimental series, even if small, provided valuable guide lines for future experimentation. The high maturation rate under these conditions now permits its reliable use for a more sensitive analysis of the roles each component plays in the medium. After the establishment of the elaborate sequences of events to the structural changes in the three compartments of the cumulus-oocyte complexes, now meaningful structure and function relationships can be explored. The first six to eight hours of culture with gonadotrophins, estradiol-17 $\beta$ and a suspension of granulosa cells, during which few morphological changes are manifested, probably represent from the physiological point of view, a very active period. This can be measured by the incorporation of labelled amino acids, nucleocides and choline. The electrophoretic pattern of proteins has already revealed the appearance within this period at least of one specific protein (Moor and Gandolfi, 1987) whose transcription takes place also after the COCs are exposed to gonadotrophic hormones in culture.

Preliminary experiments have been initiated to elaborate further, for example, the role of the two contractile processes described in detail above: (1) the chromosomal condensation in relationship to deformation of the germinal vesicle and probably also with GVBD ; and (2) expansion of the corona cells and the role of this « contractile" activity on the problem under study in its entirity : meiotic maturation and the development of competance of the oocyte for its future differentiation into the most complex cell, the totipotent oocyte.

In the in vitro system meiotic maturation can be divided into physiological events which concern the development of the competent oocyte and the 
mechanism assuring its growth on the one hand and the development of a mechanism to assure fail-safe fertilizability, the cumulus complex and the glucose-amino-glycans. Oocyte maturation is not impossible without gonadotrophins, but without such stimulation, it lacks the necessary timing and synchronization between the oocyte and the cumulus. Without gonadotrophins the dispersion of CG clusters and their peripheral migration is either reduced or inhibited all together. The evagination of the termini of the corona cell foot processes and the elimination of the heterologous junctional complexes is also slowed down. The corona cells are very sensitive indicators of the hormone levels and/or the length of time of exposure to them. Some cellular elongation and development of cellular asymmetry is initiated by $6 \mathrm{~h}$ of hormone treatment with oriented $\mathrm{mts}$ and actin filaments but the morphological transformations remain very partial. The homologous and heterologous junctions are, however, dismantled nevertheless when 6-12 h of culture without hormones follows the initial $6 \mathrm{~h}$ period with hormones. The foot process withdrawal is also perturbed. The COC culture system will be helpful in resolving these questions experimentally.

On the other hand when COCs are cultured with the full hormone complement within 6-8 $\mathrm{h}$ the oocyte becomes isolated from its corona cell neighbours ; a system excellently suited to study the carrier mediated substrate uptake mechanisms (Moor and Gandolfi, 1987). The respective roles and contributions of FSH and LH are equally approachable. Finally the COC culture system is particularly well suited to study the protein synthetic pattern during the various phases of meiotic maturation.

Reçu en octobre 1987. Accepté en avril 1988.

Acknowledgments. - We are greatful to Dr. R. M. Moor for inviting one of us (V.D.) to his laboratory in Cambridge to teach us his techniques for follicle isolation and COCs culture. His comments, direction and willingness in sharing his experiences contributed greatly to the development of our successful culture system. Our thanks are also due to Pascale Le Guen for permitting us to cite her unpublished data, and to Michel Guillaumot for help with the densitometric recordings.

The partial financial support by ATP, I.N.R.A. 1985-86 : « Hormones hypophysaires et fonction de reproduction chez les Vertébrés " is greatefully acknowledged.

We acknowledge particularly the kindness of Professors Ch. Thibault and R. H. F. Hunter for having made carefull comments and improvements in the text.

The very efficient help of Daniel Huneau in sperm capacitation contributed greatly to the success for the preparation of the " biological control » specimens. We appreciated also his critical comments on the manuscript.

Résumé. Maturation in vitro de lovocyte de brebis.

Le développement d'un système in vitro a permis d'obtenir la maturation complète de $98 \%$ d'ovocytes issus de follicules ovariens de 2 à $6 \mathrm{~mm}$ de diamètre. Le taux de fécondation de ces ovocytes, déterminé par la présence de 2 pronuclei, de l'expulsion du $2^{\circ}$ globule polaire et de la présence de la queue du spermatozoïdes dans le cytoplasme, est de $45,7 \%$. 
Ce système de culture a été utilisé pour décrire les changements morphologiques qui interviennent au cours de la maturation méïotique au niveau du noyau, du cytoplasme et des relations des cellules périovocytaires avec l'ovocyte. La maturation de l'ovocyte de brebis a lieu en $24 \mathrm{~h}$ et nécessite la présence dans le milieu de culture de FSH, LH $(10 \mu \mathrm{g} / \mathrm{ml}$ chacune $)$, d'œstradiol- $17 \beta(1 \mu \mathrm{g} / \mathrm{ml})$ et de cellules de la granulosa murale $\left(10^{6} / \mathrm{ml}\right)$ (Crozet et al., 1987).

Les premiers signes de transformation sont des changements nucléaires. Tout d'abord, la condensation de la chromatine entraîne une déformation du noyau, suivie de la rupture de la vésicule germinative, puis de la formation de fuseaux méiotiques l et II. L'axe des deux fuseaux méiotiques est orienté perpendiculairement à la membrane plasmique de l'œuf. A chaque pôle, les centres organisateurs des microtubules sont constitués d'un matériel filamenteux. L'événement majeur peut être l'initiation et le contrôle de la condensation chromosomique.

Des changements cytoplasmiques apparaissent avec le développement d'une couche corticale de 1 à $4 \mu \mathrm{m}$, appauvrie en organites cellulaires. L'appareil de Golgi se localise en trois régions distinctes pouvant correspondre à différentes fonctions: 1) autour de la vésicule germinative ; 2 ) dans la région subcorticale de l'ovocyte ; 3 ) dans la partie centrale de l'ovocyte. Les granules corticaux à différents stades de maturation (condensation) sont d'abord disposés en amas à la périphérie de l'appareil de Golgi ; lors de la métaphase I ils s'alignent en une monocouche continue le long de la membrane plasmique de l'ovocyte. En métaphase II, les granules corticaux semblent être accrochés à la membrane cellulaire par des filaments.

Les cellules du cumulus (corona) sont en contact les unes avec les autres et avec l'ovocyte par des jonctions électroniques et structurales. Les pieds cellulaires traversent la zone pellucide et entrent en contact avec l'ovocyte. Les terminaisons se rétractent progressivement et les contacts sont rompus conduisant à isoler l'ovocyte.

L'ensemble de ces changements représente la maturation méiotique.

\section{References}

ANDERSON E., 1977. Junctional complexes in the developing ovarian follicle and preimplantation mammalian embryo with particular reference to gap junctions. Res. Reprod., 9, No. 5.

ANDERSON E., ALBERTINI D. F., 1976. Gap junctions between the oocyte and companion follicle cells in the mammalian ovary. J. Cell Biol., 71, 680-686.

CALARCO P. G., DONAHUE R. P., SZÖLLÖSI D., 1972. Germinal vesicle breakdown in the mouse oocyte. J. Cell Sci., 10, 1-17.

CALARCO-GILLAM P. D., SIEBERT M. C., HUBBLE R., MITCHISON T., KIRCHNER M., 1983. Centrosome development in early mouse embryos as defined by an auto-antibody against pericentrosomal material. Cell, 35, 621-629.

CHURCH K., 1977. Chromosome ends and the nuclear envelope at premeiotic interphase in the male grasshopper Brachystola magna by 3-D E.M. reconstruction. Chromosoma, 64, 143-154.

CRAN D. G., 1987. The distribution of organelles in mammalian oocytes following centrifugation prior to injection of foreign DNA. Gamete Res., 18, 67-76.

CRAN D. G., CHENG W. T. K., 1985. Changes in cortical granules during porcine oocyte maturation. Gamete Res., 11, 311-319.

CRAN D. G., MOOR R. M., HAY M. F., 1980. Fine structure of sheep oocyte during antral follicle development. J. Reprod. Fert., 59, 125-132.

CROSS P. C., BRINSTER R. L., 1970. In vitro development of mouse oocytes. Biol. Reprod., 3. 298-307.

CROZET N., SZÖLLÖSI D., 1981. Evolution of nucleolar fine structure and RNA synthesis of porcine oocytes during the early stages of antrum formation, 265-269. In Follicular maturation and ovulation. ROLLAND R., VAN HALL E. V., HILLIER S. G., MCNATTY K. P., SCHOEMAKER J. Excerpta medica. 
CROZET N., KANKA J., MOTLIK J., FULKA J., 1986. Nucleolar fine structure and RNA synthesis in bovine oocytes from antral follicles. Gamete Res., 14, 65-73.

CROZET N., HUNEAU D., DESMEDT V., THÉRON M.-C., SZÖLLÖSI D., TORRĖS S., SEVELLEC C., 1987. In vitro fertilization with normal development in the sheep. Gamete Res., 16. 159-170;

CUMMINGS D. Eq., OKADADA T. A., 1970. Association of chromatin fibers with the annuli of the nuclear membrane. Exp. Cell Res., 62, 293-302.

DARLINGTON C. D., LACOUR L. F., 1960. The handling of chromosomes. George Allen \& Unwin Ltd., London.

EPPIG J. J., 1979. A comparison between oocyte growth in co-culture with granulosa cells and oocytes with granulosa cell-oocyte junctional contact maintained in vitro. J. exp. Zool., 209, 345-353.

EPPIG J. J., 1982. The relationship between cumulus cell-oocyte coupling, oocyte meiotic maturation and cumulus expansion. Dev. Biol., 89, 268-272.

FARQUHAR M. G., PALADE G. E., 1981. The Golgi apparatus (complex)-(1954-1981)-from artifact to center stage. J. Cel/ Biol., 91, 77s-103s.

FLEMMING A. D., EVANS G., WALTON A., ARMSTRONG D. T., 1985. Developmental capability of rat oocytes matured in vitro in defined media. Gamete Res., 12, 255-269.

FRANKE W. W., SCHEER U., KROHNE G., JARASCH E.-D., 1981. The nuclear envelope and the architecture of the nuclear periphery. J. Cell Biol., 91, 39s-50s.

GÉRARD M., MEENÉZO Y., ROMBAUTS P., SZÖLLÖSI D., THIBAULT C., 1979. In vitro studies of oocyte maturation and follicular metabolism in the pig. Ann. Biol. anim. Bioch. Biophys., 19. $1521-1535$

GILULA N. B., EPSTEIN M. L., BEERS W. H., 1978. Cell-to-cell communication and ovulation. A study of the cumulus-oocyte complex. J. Cell Biol., 78, 58-75.

HELLER D. T., CAHIL D. M., SCHULTZ R. M., 1981. Biochemical studies of mammalian oogenesis. Cooperativity between granulosa cells and growing mouse oocytes. Dev. Biol., 84, 455-464

HYTTEL P., 1987. Bovine cumulus-oocyte disconnection in vitro. Anat. Embryol., 176, 41-44.

HYTTEL P., CALLESEN H., GREVE T., 1986a. Ultrastructural features of preovulatory oocyte maturation in superovulated cattle. J. Reprod. Fert., 76, 645-656.

HYTTEL P., XU K. P., SMITH S., CALLESEN H., GREVET., 1986b. Ultrastructure of the final nuclear maturation of bovine oocytes in vitro. Anat. Embryol., 176, 35-40.

HYTTEL P., XU K. P., SMITH S., GREVE T., 1986c. Ultrastructure of in vitro oocyte maturation in cattle. J. Reprod. Fertil., 78, 645-656.

KRUIP T. A. M., CRAN D. G., van BENEDEN T. H., DIELEMAN S. J., 1983. Structural changes in bovine oocytes during final maturation in vivo. Gamete Res., 8, 29-47.

LARSEN W. J., WERT S. E., BRUNNER G. D., 1986. A dramatic loss of cumulus cell gap junctions is correlated with germinal vesicle breakdown in rat oocytes. Dev. Biol., 102, 517-521.

LONGO F. J., 1985. Fine structure of the mammalian egg cortex. Am. J. Anat., 174, 303-315.

LONGO F. J., 1987. Actin-plasma membrane associations in mouse eggs and oocyte. J. exp. Zool., 243, 299-309.

LONGO F. J., CHEN D. Y., 1985 . Development of cortical polarity in mouse eggs : involvement of the meiotic apparatus. Dev. Biol., 107, 382-394.

MARO B., HOWLETT S. K., WEBB M., 1985. Non-spindle microtubule organizing centers in metaphase II-arrested mouse oocytes. J. Cell Biol., 101, 1665-1672.

MAUL G. G., SCHATTEN G., 1986. Nuclear lamins during gametogenesis, fertilization and early development, 123-134. In PETERS R., TRENDELBURG M., Nucleocytop/asmic transport, Springer-Verlag, Berlin.

MILLONIG G., MARINOZZI V., 1968. Fixation and embedding in electron microscopy. In BARER R., COSSLETT V. E., Adv. Optical and Electron Microscopy, Vol. 2, p. 251-341.

MOËNS P. B., 1969. The fine structure of meiotic chromosome polarization and pairing in Locusta migratoria spermatocytes. Chromosoma, 28, $1-25$.

MOOR R. M., SMITH M. W., DAWSON R. M. C., 1980. Measurement of intercellular coupling between oocytes and cumulus cells using intracellular markers. Exp. Cel/ Res., 126, 15-29.

MOOR R. M., GANDOLFI F., 1987. Molecular and cellular changes associated with maturation and early development of sheep eggs. J. Reprod. Fert., Suppl. 34, 55-69. 
MORICARD R., MORICARD F., 1975. Espace périvitellin et réaction microvillositaire au cours de l'achèvement de la méiose et de la fécondation chez les mammifères; orientation des recherches humaines, 37-46. In THIBAULT C., La fécondation, Masson et Cie, Paris.

MOTLIK J., FULKA J., 1974a. Fertilization of pig oocytes cultivated in vitro. J. Reprod. Fert., 31, 235-237.

MOTLIK J., FULKA J., 1974b. Fertilization in vivo of rabbit oocytes cultivated in vitro. J. Reprod. Fert., 40, 183-186.

MOTLIK J., FULKA J., 1982. Fertilization and developmental capacity of mammalian oocytes cultured in vitro, 142-145. In MERIEUX C., BONNEAU M., Embryo transfer in mammals. Annecy.

MOTLIK J., FULKA J., FLECHON J.-E., 1986. Changes in intercellular coupling between pig oocytes and cumulus cells during maturation in vivo and in vitro. J. Reprod. Fert., 76, 31-37.

OKADA A., YANAGIMACHI R., YANAGIMACHI H., 1986. Development of cortical granules free area of cortex and the perivitellin space in the hamster oocyte during maturation and following ovulation. Submicrosc. Cytol., 18, 233-247.

OSBORN J. C., MOOR R. M., 1983. The role of steroid signals in the maturation of mammalian oocytes. J. Steroid Biochem., 19, 133-137.

RIME H., JESSUS C., OZON R., 1987. Distribution of microtubules during the first meiotic cell division in the mouse oocyte : effect of taxol. Gamete Res., 17, 1-13.

RIME H., JESSUS C., OZON R., 1988. Estramustine phosphate inhibits germinal vesicle breakdown and induces depolymerization of microtubules in mouse oocytes. Reprod. Nutr. Dév., 28, 319-334.

SATO E., WOOD H., LYNN D. G., KOIDE S. S., 1985. Modulation of oocyte maturation by cyclic adenosine $3^{\prime}, 5^{\prime}$-pyrophosphate. Cell Differ., 17, 169-174.

SATO E., KOIDE S. S., 1987. Biochemical transmitters regulating the arrest and resumption of meiosis in oocytes. Int. Rev. Cytol., 106, 1-33.

SCHATTEN H., SCHATTEN G., MAZIA D., BALCZON R., SIMMERLY C., 1986. Behaviour of centrosomes during fertilization in mouse oocytes and in sea urchin eggs. Proc. nat. Acad. Sci. USA, 83, 105-109.

SCHROEDER A. C., EPPIG J. J., 1984. The developmental capacity of mouse oocytes that mature spontaneously in vitro is normal. Dev. Biol., 102, 493-498.

SCHULTZ R. M., 1987. Molecular aspects of mammalian oocyte growth and maturation. In Experimental approaches to mammalian embryonic development. Cambridge Univ. Press.

SENGER P. L., SAACKE R. G., 1970. Usual mitochondria of the bovine oocyte. J. Cell Biol., 46, 405-408.

SHALGI R., PHILIPS D. M., 1980. Mechanics of in vitro fertilization in the hamster. Biol. Reprod., 23, 433-444.

SHERIZLY I., GALIANI D., DEKEL N., 1987. Regulation of maturation of rat oocytes. Communication in the cumulus oocyte complex. Mol. cell. Endocrinol. (submitted).

SNOW C. M., SENIOR A., GERACE L., 1987. Monoclonal antibodies identify a group of nuclear pore complex glycoproteins. J. Ce/l Biol., 104, 1143-1156.

STAIGMILLER R. B., MOOR R. M., 1984. Effect of follicle cells on the maturation and developmental competence of ovine oocytes matured outside the follicle. Gamete Res., 9, 221-229.

SZÖLLOSI D., 1975. Ultrastructural aspects of oocyte maturation and fertilization in mammals, 15-35. In C. THIBAULT, La fécondation, Masson \& Co., Paris.

SZOLLOSI D., 1978. On the role of gap junctions found between follicle cells and oocyte in the mammalian ovarian follicle. Res. Reprod., 10, No. 2.

SZÖLLOSI D., CALARCO P. G., DONAHUE R. P., 1972a. Absence of centrioles in the first and second meiotic spindle of mouse oocytes. J. Cell Sci., 11, 521-541.

SZÖLLÖSI D., CALARCO P. G., DONAHUE R.P., 1972b. The nuclear envelope $:$ its breakdown and fate in mammalian oogonia and oocytes. Anat. Rec., 174, 325-340.

SZÖLLOSI D., GÉRARD M., MÉNEZZ Y., THIBAULT C., 1978. Permeability of ovarian follicle ; corona cell-oocyte relationship in mammals. Ann. Biol. anim. Bioch. Biophys., 18, 511 -521.

SZÖLLÖSI D., GÉRARD M., 1983. Cytoplasmic changes in mammalian oocytes during preovulatory period, 35-55. In BEIER H. M., LINDNER H., Fertilization of the human egg in vitro. Springer Verlag, Berlin. 
SZÖLLÖSI D., CZOLOWSKA R., SOLTYNSKA M. S., TARKOWSKI A. K., 1986a. Ultrastructure of cell fusion and premature chromosome condensation (PCC) of thymocyte nuclei in metaphase II mouse oocytes. Biol. Cell, 56, 239-250.

SZÖLLÖSI D., MANDELBAUM J., PLACHOT M., SALAT-BAROUX L., COHEN J., 1986b. Ultrastructure of the human preovulatory oocyte. J. Fert. Embryo Trans., 3, 232-242.

THIBAULT C., 1967. Analyse comparée de la fécondation et de ses anomalies chez la brebis, la vache et la lapine. Ann. Biol. anim. Bioch. Biophys., 7, 5-29.

THIBAULT C., 1972. Meiotic maturation of mammalian ovarian oocytes, 397-411. In BIGGERS J. D., SCHUETZ A. W., Oogenesis, Univ. Park Press, Baltimore.

THIBAULT C., 1977. Are follicular maturation and oocyte maturation independent processes ? J. Reprod. Fert., 51, 1-15.

THIBAULT C., GERARD M., 1970. Facteur cytoplasmique nécessaire à la formation du pronucleus mâle dans l'ovocyte de lapine. C. R. Acad. Sci. Paris, 270, 2025-2026.

THIBAULT C., GÉRARD M., MÉNEZZO Y., 1975. Acquisition par l'ovocyte de lapine et de veau du facteur de décondensation du noyau du spermatozoide fécondant (MPGF). Ann. Biol. anim. Bioch. Biophys., 15, 705-714.

THIBAULT C., SZÖLLOOSI D., GERARD M., 1987. Mammalian oocyte maturation. Reprod. Nutr. Dévelop., 27, 865-896.

TSAFRIRI A., CHANNING C. P., 1975. An inhibitory influence of granulosa cells and follicular fluid upon porcine meiosis in vitro. Endocrinology, 96, 922-927.

UNWIN P. N. T., MILLIGEN R. A., 1982. A large particle associated with perimeter of the nuclear pore complex. J. Cell Biol., 93, 63-75.

WASSARMAN P. M., LETOURNEAU G. E., 1976. RNA synthesis in fully grown mouse oocytes. Nature, 261, 73-74.

ZAMBONI L., 1970. Ultrastructure of mammalian oocytes and ova. Biol. Reprod., Suppl. 2, 44-63.

ZAMBONI L., 1972. Comparative studies on the ultrastructure of mammalian oocytes, $5-45$; in BIGGERS J. D., SCHUETZ A. W., Oogenesis, Univ. Park Press, Baltimore. 